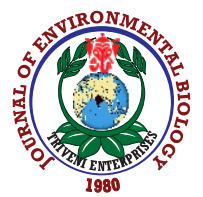

\title{
Impact of biochar on nutrient uptake by tomato, residual soil properties and acidity indices in acid Inceptisol of Meghalaya
}

\section{O.S. Yadav*, Sanjay-Swami and T.V. Sowjanya}

School of Natural Resource Management, College of Post Graduate Studies in Agricultural Sciences, Central Agricultural University, Umiam (Barapani) - 793 103, India

*Corresponding Author Email : oguboina.srikanthyadav@gmail.com

\section{Abstract}

Aim: To investigate the impact of biochar as component of integrated nutrient management on nutrient uptake by tomato in acid soil of Meghalaya, North East India.

Methodology: A field experiment was conducted at research farm of SNRM, College of Post Graduate Studies in Agricultural Sciences (CPGS-AS), Central Agricultural University (CAU-I), Umiam during rabi 2017-18 taking tomato, cv. Megha Tomato-2 as test crop. Sixteen treatment combinations of recommended closes of fertilizers, biochar and vermicompost were tested in RBD with three replications.

Results: The experimental results revealed that combined application of biochar, fertilizers and vermicompost increased the uptake and availableof $\mathrm{N}, \mathrm{P}, \mathrm{K}, \mathrm{Fe}, \mathrm{Zn}, \mathrm{Mn}$ and $\mathrm{Cu}$ over graded doses of biochar + fertilizers, biochar alone and control. Electrical conductivity, bulk density, exchangeable acidity, exchangeable aluminium and acid saturation followed the same trend.

Interpretation: The 100\% RDF + biochar 4 tha $^{-1}$ + vermicompost @ 2.5 t ha $^{-1}$ is the most appropriate combination for increasing tomato productivity and improving soil health of acidic soil in Meghalaya.

Key words: Acid soil, Biochar, Integrated nutrient management, Tomato

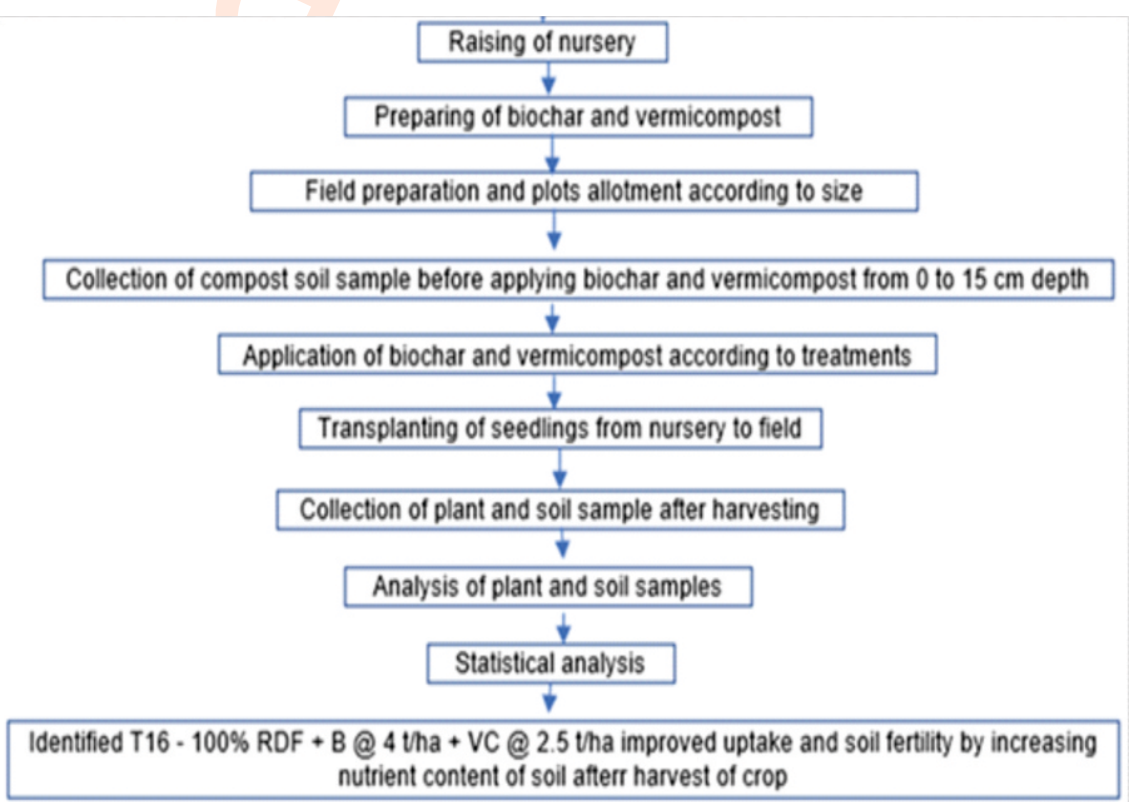

How to cite : Yadav, O.S., Sanjay-Swami and T.V. Sowjanya: Impact of biochar on nutrient uptake by tomato, residual soil properties and acidity indices in acid Inceptisol of Meghalaya. J. Environ. Biol., 41, 1761-1773 (2020). 


\section{Introduction}

Soil is the basic foundation of sustainable crop production and the soil quality impacts crop production. Out of 142 million ha of cultivable land in India, 49 million ha of land is acidic, of which 26 million ha of land having soil pH less than 5.5 and the rest 23 million ha of land having soil $\mathrm{pH}$ range 5.6 to 6.5 . About 21 million ha of acid soils are found in North Eastern Hill (NEH) region, including Sikkim with the maximum area under Arunachal Pradesh. In Meghalaya, the soils under various acidic ranges are found like moderately acidic soil (1.19 million ha), and slightly acidic soils (1.05 million ha) (Maji et al., 2012). The soils of Meghalaya are rich in organic carbon, which is a measure of nitrogen supplying potential of soil, deficient in available phosphorous, medium to low in available potassium, calcium, magnesium and toxic in $\mathrm{Al}$ and Fe. To overcome the problem of soil acidity, farmers adopt a variety of soil amendments like manures, lime, compost, and bio-sorbents to make soil nutrients available to crops as well as to protect them from toxic elements. Among soil amendments, liming is good practice to overcome the acidity problem. However, it may not be economical in the regions where it is expensive. The alternate cheap and good organic source to overcome the acidity problem is biochar (Chan et al., 2008).

Biochar is a carbonaceous solid material obtained through thermally degrading process of biomass in presence of little oxygen. It is generally defined as charred organic matter, produced with the interest to apply into soils to improve soil properties and sequester carbon (Lehmann and Joseph, 2009). Biochar is produced through pyrolysis which is the direct thermal decomposition of biomass in the absence of oxygen that produces a mixture of solids (biochar), liquid (bio-oil), and gas (syngas). Quality and yield of biochar depend on maintaining a specific temperature (Demirbas, 2004). The temperature of 400 $500^{\circ} \mathrm{C}$ produces more biochar, while temperatures above $700^{\circ} \mathrm{C}$ favour the yield of liquid and gas fuel components. The major resource required for the production of biochar is organic residue and/or weed biomass. North Eastern Hill (NEH) region of India produces a huge amount of weed biomass, crop residues and have large forest area making easy availability of different biomass for converting into biochar quantify (CRIDA, 2012).

The characteristics of biochar mainly depends on type of resource used for the preparation of biochar. These are governed by its chemical and physical constituents. The form and size of resources and pyrolysis product may affect the quality and potential uses of biochar (Sohi et al., 2010). Biochar was found to be beneficial in various ways such as : moderating of soil acidity by one point increase in $\mathrm{pH}$ (Lehman and Rondon, 2006), reducing methane gas emission (Rondon et al., 2005), decreasing emissions of nitrous oxide (Yanai et al., 2007), increasing cation exchange capacity (Glaser et al., 2002), soil moisture retention (Tryon, 1948), decreasing soil bulk density
(Laird, 2008), increasing number and activity of beneficial soil microbes (Warnock et al., 2007), improving fertilizer use efficiency (Gaunt and Cowie, 2009). The usefulness of biochar increases when it is applied in combination with organic manures like FYM, vermicompost, poultry manure, pig manure (CRIDA, 2012). The state of Meghalaya is known for large array of vegetables both sub-tropical and temperate. Tomato (Solanum lycopersicum L.) is one of the most important vegetable crops supporting the livelihood and improving the economic life of many vegetable growers in the NEH region of India. It is used as a vegetable, soup, salad, pickle, ketchup, sauce and many other ways. It is a good source of vitamin A, B, and C. Keeping these facts in view, the present investigation was carried out to study the impacts of biochar and vermicompost on nutrient uptake (N, P, K and micro-nutrients) by tomato in acid soil of Meghalaya and determine the residual soil properties, nutrient availability and soil acidity indices.

\section{Materials and Methods}

Study site: The field experiment was conducted at the Research Farm of School of Natural Resource Management, College of Post Graduate Studies in Agricultural Sciences (CPGS-AS), Umiam, Ri-bhoi district, Meghalaya which is located at $91^{\circ} 18^{\prime}$ to 92 $18^{\prime}$ E longitude and $25^{\circ} 40^{\prime}$ to $26^{\circ} 20^{\prime} \mathrm{N}$ latitude at an altitude of $950 \mathrm{~m}$ above mean sea level. The experimental area falls under subtropical humid climate with high rainfall and cold winter.

Experiment set up: Tomato (cv. Megha tomato-2) was used as test crop for investigating the performance with 16 combinations of three doses of biochar (B) @ 2, 3 and 4 t/ha, two graded recommended doses of fertilizers (RDF) @ 75 and 100\% and one dose of vermicompost (VC) @ $2.5 \mathrm{t} \mathrm{ha}^{-1}$. The treatment combinations namely, $\mathrm{T}_{1}$ - Control, $\mathrm{T}_{2}$ - B @ 2 t ha $\mathrm{t}^{-1}, \mathrm{~T}_{3}$ - B @ 3 tha $\mathrm{t}^{-1}$, $\mathrm{T}_{4}-\mathrm{B} @ 4$ tha ${ }^{-1}, \mathrm{~T}_{5}-75 \% \mathrm{RDF}+\mathrm{B} @ 2 \mathrm{tha}^{-1}, \mathrm{~T}_{6}-75 \% \mathrm{RDF}+\mathrm{B} @ 3 \mathrm{t}$ ha $^{-1}, \mathrm{~T}_{7}-75 \%$ RDF + B @ 4 tha $^{-1}, \mathrm{~T}_{8}-75 \%$ RDF + B @ 2 tha $^{-1}+\mathrm{VC}$ @ 2.5 t ha $^{-1}, \mathrm{~T}_{9}-75 \%$ RDF+B @ 3 tha $^{-1}+\mathrm{VC} @ 2.5$ tha $^{-1}, \mathrm{~T}_{10}-75 \%$ RDF + B @ 4 tha $^{-1}+V C @ 2.5$ tha $^{-1}, T_{11}-100 \%$ RDF + B @ 2 tha $^{-1}$, $\mathrm{T}_{12}-100 \%$ RDF + B @ 3 tha $^{-1}, \mathrm{~T}_{13}-100 \%$ RDF + B @ $4 \mathrm{t} \mathrm{ha}^{-1}, \mathrm{~T}_{14^{-}}$ $100 \%$ RDF + B @ 2 tha $^{-1}+V C @ 2.5$ tha $^{-1}, T_{15}-100 \%$ RDF + B @ 3 tha ${ }^{-1}+$ VC @ 2.5 tha $^{-1}, T_{16}-100 \%$ RDF + B@ 9 t ha ${ }^{-1}+$ VC @2.5t $\mathrm{ha}^{-1}$. They were randomly allotted in a unit plot size of $2 \mathrm{~m} \times 2 \mathrm{~m}$. The experiment was replicated three times in Randomized Block Design (RBD). The nutrients N, P and $\mathrm{K}$ were applied through urea, single super phosphate and murate of potash, respectively, on the day of sowing whereas vermicompost and biochar was applied ten days prior to transplanting as per treatment wise. Seedlings of tomato were transplanted to the plots with $40 \times 40$ $\mathrm{cm}^{2}$ spacing during rabi season of 2017-2018. The desired plant population was maintained uniformly by gap filling. Watering and hand weeding was carried out as and when required. The fruits were harvested in several pickings according to their physiological maturity. 
Sampling and analysis: Bulk sample of biochar was collected from the Department of Agricultural Engineering, ICAR Research Complex for North Eastern Hill Region, Umiam (Barapani), Ribhoi district, Meghalaya. The feedstock used for preparation of biochar was waste from plywood industry and it was prepared at 450 to $600^{\circ} \mathrm{C}$. The vermicompost used in this study was collected from Rural Resource and Training Centre, Umran, Meghalaya. The representative samples of biochar and vermicompost were brought to the laboratory for analysis. The physico-chemical properties of biochar and vermicompost were estimated by standard methods: $\mathrm{pH}$ ( 8.60 and 7.30 ) by potentiometry, nitrogen (0.61 and $2.11 \%$ ) by Kjeldahl digestion and distillation method, phosphorus ( 0.22 and $1.23 \%$ ) by Vanadomolybdate method, potassium (1.01 and $1.53 \%$ ) by flame photometer method (Jackson, 1973), iron (0.06 and $250.20 \mathrm{ppm})$, zinc (1.72 and $1095.00 \mathrm{ppm})$, manganese (0.04 and $53.00 \mathrm{ppm})$, copper (0.12 and $248.60 \mathrm{ppm}$ ) by atomic absorption spectrophotometer (Lindsay and Norwell, 1978).

The composite soil sample from 0 to $15 \mathrm{~cm}$ depth was collected from the experimental area before land preparation using standard methods. Again the soil samples were collected after harvesting of crop and five plants were selected randomly in the net plot area and labeled for recording observations in each treatment. The soil samples were air dried ground and passed through $2 \mathrm{~mm}$ sieve for analysis of physico-chemical properties following standard protocol as $\mathrm{pH}, \mathrm{EC}\left(\mathrm{dS} \mathrm{m}^{-1}\right)$, available $\mathrm{K}_{2} \mathrm{O}(\mathrm{kg}$ $\left.h^{-1}\right)$, exchangeable acidity, exchangeable aluminium, exchangeable $\mathrm{Ca}$ and $\mathrm{Mg}$, cation exchange capacity by Jackson (1973), bulk density $\left(\mathrm{g} \mathrm{cm}^{-3}\right)$ by Campbell and Henshall (2001), available $\mathrm{N}\left(\mathrm{kg} \mathrm{ha}^{-1}\right.$ ) by Subbiah and Asija (1956), available $\mathrm{P}_{2} \mathrm{O} 5$ (kg ha') by Bray and Kurtz (1945). Fe, Zn, Mn and Cu were estimated by the method of Lindsay and Norwell (1978). Nitrogen in plant samples was determined by Kjeldahl digestion distillation method as described by Jackson (1973). Digestion of fruit and plant samples was carried out with di-acid mixture containing $\mathrm{HNO}_{3}$ and $\mathrm{HClO}_{4}$ in the ratio of $3: 1$ and further used for determination of $\mathrm{P}, \mathrm{K}, \mathrm{Fe}, \mathrm{Zn}, \mathrm{Mn}$ and $\mathrm{Cu}$ by above stated standard protocol.

Nutrient uptake : N, $\mathrm{P}$ and $\mathrm{K}$ uptake in both fruit and haulm were calculated by the following formula:

Nutrient uptake $\left(\mathrm{kg} \mathrm{ha}^{-1}\right)=$ Nutrient concentration $(\%) x y i e l d\left(\mathrm{tha}^{-1}\right)$ $\mathrm{x} 10$

Micronutrients uptake in both fruit and haulm were calculated by using the following formula:

Nutrient uptake $\left(\mathrm{g} \mathrm{ha}^{-1}\right)=$ Nutrient concentration $(\mathrm{ppm}) \times$ yield $\left(\right.$ tha $\left.^{-1}\right)$

Soil acidity indices : Soil acidity indices as described by Fageria, (2008) were estimated by the standard methods and calculated with the help of the following formulas:

$$
\mathrm{CEC}\left(\mathrm{cmol}_{\mathrm{c}} \mathrm{kg}^{-1}\right)=\Sigma\left(\mathrm{Ca}^{2+}, \mathrm{Mg}^{2+}, \mathrm{K}^{+}, \mathrm{H}^{+}, \mathrm{Al}^{3+}\right)
$$

Where, $\mathrm{Ca}, \mathrm{Mg}, \mathrm{K}, \mathrm{H}$ and $\mathrm{Al}$ are in centimoles of positive charge per kilogram.

$$
\begin{gathered}
\text { Base saturation }(\%)=\frac{\Sigma\left(\mathrm{Ca}^{2+}, \mathrm{Mg}^{2+}, \mathrm{K}^{+}, \mathrm{H}^{+}, \mathrm{Al}^{3+}\right)}{\mathrm{CEC}} \times 100 \\
\text { Acidity saturation }(\%)=\frac{(\mathrm{H}+\mathrm{Al})}{\mathrm{CEC}} \times 100
\end{gathered}
$$

Statistical analyses : The data obtained from the experiment were analyzed for analysis of variance (ANOVA) and the difference between treatment means was tested for their statistical significance with appropriate critical difference $(C D)$ at $5 \%$ level of probability (Gomez and Gomez, 1984).

\section{Results and Discussion}

The statistics have-to-do with nitrogen concentration (\%) and uptake ( $\left.\mathrm{kg} \mathrm{ha}^{-1}\right)$ in fruit and haulm dry matter as affected by biochar as a component of integrated nutrient management are presented in Table 1. The highest nitrogen concentration in fruit and haulm was noticed in the treatment receiving 100\% RDF + biochar 4 t ha ${ }^{-1}+$ vermicompost 2.5 t ha $^{-1}$ (T16) with 46 and $45 \%$ increase over control, respectively. Similar trend was also obtained in the case of nitrogen uptake ( $\left.\mathrm{kg} \mathrm{ha}^{-1}\right)$ in fruit and haulm dry matter, and the highest nitrogen uptake $\left(\mathrm{kg} \mathrm{ha}^{-1}\right)$ in fruit and haulm was recorded 51.26 and $37.80 \mathrm{~kg} \mathrm{ha}^{-1}$, whereas the lowest $\mathrm{N}$ uptake in fruit and haulm was recorded as 5.74 and $3.70 \mathrm{~kg} \mathrm{ha}^{-1}$ in control treatments. The sole application of biochar has showed a slight increase in nitrogen concentration with increasing the doses of biochar in fruit and haulm. Addition of $75 \%$ RDF with biochar showed a significant increase over sole application of biochar at $4 \mathrm{t}$ $\mathrm{ha}^{-1}$ in fruit, but in haulm. The application of 100\% RDF in the combination of biochar slightly increased nitrogen concentration over $75 \%$ RDF in combination with biochar, whereas it showed a significant increase over the sole application of biochar. The application of vermicompost in combination with $75 \%$ RDF + biochar showed slight increase over combined application of $75 \%$ RDF + biochar and this increase was observed to be significant over sole application of biochar. The concentration of nitrogen in fruit and haulm was found less with 75\% RDF + biochar + vermicompost in comparison to that observed under $100 \%$ RDF + biochar. Further, the addition of vermicompost with $100 \%$ RDF + biochar reflected a slight increase over combined application of $75 \%$ RDF + biochar + vermicompost, $75 \%$ RDF + biochar and $100 \%$ RDF + biochar but it had increased significantly over sole application of biochar $\left(\mathrm{T}_{2}, \mathrm{~T}_{3}, \mathrm{~T}_{4}\right)$.

The data relevant to nitrogen uptake revealed that the highest uptake in fruit and haulm (51.26 and $37.8 \mathrm{~kg} \mathrm{ha}^{-1}$ ) in the 
treatment receiving 100\% RDF + biochar 4 tha $^{-1}+$ vermicompost $2.5 \mathrm{tha}^{-1}\left(\mathrm{~T}_{16}\right)$ whereas the lowest values of nitrogen uptake in fruit and haulm (5.74 and 3.70) was recorded under control plots. It was observed that nitrogen uptake was significantly increased by the addition of $75 \%$ RDF with biochar over sole application of biochar as well as over control. Similarly, it increased significantly with the inclusion of vermicompost with RDF + biochar @ 4 t ha $^{-1}$ over RDF + biochar @ 4 t ha ${ }^{-1}$. The fruit and haulm dry matter recorded higher nitrogen concentration and uptake in the plots treated with biochar in the combination of inorganic fertilizers and organic manures might be due to decrease in nitrogen loss and slow release pattern of nitrogen synchrony with the demand of tomato crop. Lehmann et al. (2003a), Zhang et al. (2017) and McDonald et al. (2019) reported that insertion of biochar enhanced nitrogen uptake. The escalated in nitrogen concentration on supplying biochar was also suggested by Glaser et al. (2002) and Lehmann et al. (2003b). The improved in nitrogen uptake in plants on adding biochar was also observed by Agegnehu et al. (2015); Butnan et al. (2015) and Zwieten et al. (2010). Similar to these findings, Chan et al. (2008) also reported high nitrogen uptake by radish plants grown in soil amended by biochar.
The particulars on phosphorus concentration showed that the control plots had $0.22 \%$ phosphorus concentration which increased up to $0.40 \%$ (Table 1). This highest phosphorus concentration (0.40\%) was observed under $\mathrm{T}_{16}$ with $100 \%$ RDF + biochar 4 tha $^{-1}+$ vermicompost 2.5 tha $^{-1}$. In the same line, highest phosphorus uptake $20.78 \mathrm{~kg} \mathrm{ha}^{-1}$ in fruit was also recorded in $\mathrm{T}_{16}$. The application of biochar showed a slight increase in phosphorus concentration on increasing the doses of biochar in fruit and haulm. Addition of $75 \%$ RDF with biochar also significantly increased phosphorus concentration in fruit and haulm over sole application of biochar at respective doses. The application of $100 \%$ RDF + biochar slightly increased phosphorus concentration than those observed with combined application of $75 \%$ RDF + biochar but showed a significant increase over sole application of biochar. The application of $75 \%$ RDF + biochar + vermicompost slightly increased phosphorus concentration over combined application of $75 \% \mathrm{RDF}+$ biochar and it has increased significantly over the sole application of biochar. Further, the concentration of phosphorus was less in $75 \%$ RDF + biochar + vermicompost then that of $100 \%$ RDF + biochar. Application of vermicompost jointly with $100 \%$ RDF + biochar had increased phosphorus concentration slightly over combined application of $75 \%$ RDF + biochar + vermicompost and 100\% RDF + biochar,

Table 1 : Impact of biochar as a component of integrated nutrient management on N, P and K concentration (\%) and uptake (kg ha $\left.{ }^{-1}\right)$ in tomato fruit and haulm dry matter

\begin{tabular}{|c|c|c|c|c|c|c|c|c|c|c|c|c|}
\hline \multirow[t]{2}{*}{ Treatments } & \multicolumn{2}{|c|}{$\mathrm{N}$ concentration } & \multicolumn{2}{|c|}{ Nuptake } & \multicolumn{2}{|c|}{ P concentration } & \multicolumn{2}{|c|}{ P uptake } & \multicolumn{2}{|c|}{ K concentration } & \multicolumn{2}{|c|}{ Kuptake } \\
\hline & Fruit & Haulm & Fruit & Haulm & Fruit & Haulm & Fruit & Haulm & Fruit & Haulm & Fruit & Haulm \\
\hline $\mathrm{T}_{1}-$ Control & 0.67 & 0.81 & 5.74 & 3.70 & 0.22 & 0.28 & 1.90 & 1.29 & 0.48 & 0.54 & 4.14 & 2.49 \\
\hline $\mathrm{T}_{2}-\mathrm{B} @ 2$ tha $^{-1}$ & 0.70 & 0.84 & 7.08 & 4.60 & 0.25 & 0.31 & 2.56 & 1.69 & 0.52 & 0.57 & 5.28 & 3.11 \\
\hline $\mathrm{T}_{3}-\mathrm{B} @ 3$ tha $^{-1}$ & 0.72 & 0.87 & 8.15 & 5.42 & 0.27 & 0.33 & 3.03 & 2.03 & 0.54 & 0.59 & 6.08 & 3.64 \\
\hline $\mathrm{T}_{4}-\mathrm{B} @ 4$ tha $^{-1}$ & 0.73 & 0.88 & 9.53 & 6.41 & 0.28 & 0.34 & 3.66 & 2.47 & 0.55 & 0.61 & 7.18 & 4.35 \\
\hline $\mathrm{T}_{5}-75 \%$ RDF+B @ 2 tha $^{-1}$ & 0.81 & 0.97 & 13.01 & 8.80 & 0.31 & 0.38 & 4.95 & 3.44 & 0.58 & 0.64 & 9.25 & 5.78 \\
\hline $\mathrm{T}_{6}-75 \% \mathrm{RDF}+\mathrm{B} @ 3$ tha $^{-1}$ & 0.84 & 1.01 & 14.87 & 10.06 & 0.33 & 0.41 & 5.87 & 4.09 & 0.60 & 0.67 & 10.65 & 6.67 \\
\hline $\mathrm{T}_{7}-75 \% \mathrm{RDF}+\mathrm{B} @ 4$ tha $^{-1}$ & 0.86 & 1.03 & 17.65 & 12.18 & 0.34 & 0.43 & 6.99 & 5.02 & 0.61 & 0.68 & 12.58 & 8.04 \\
\hline $\begin{array}{l}\mathrm{T}_{8}-75 \% \text { RDF + B @ } 2 \text { tha }^{-1}+ \\
\text { VC @ } 2.5 \text { tha }^{-1}\end{array}$ & 0.83 & 1.00 & 16.77 & 11.58 & 0.33 & 0.41 & 6.63 & 4.71 & 0.59 & 0.66 & 11.89 & 7.61 \\
\hline $\begin{array}{l}\mathrm{T}_{9}-75 \% \text { RDF + B @ } 3 \text { tha }^{-1}+ \\
\text { VC @ 2.5 tha }\end{array}$ & 0.86 & 1.04 & 32.57 & 23.15 & 0.35 & 0.43 & 13.19 & 9.61 & 0.61 & 0.69 & 22.77 & 15.28 \\
\hline $\begin{array}{l}\mathrm{T}_{10}-75 \% \text { RDF + B @ } 4 \text { tha }^{-1}+ \\
\text { VC @ } 2.5 \text { tha }^{-1}\end{array}$ & 0.88 & 1.06 & 38.15 & 27.44 & 0.36 & 0.44 & 15.59 & 11.35 & 0.62 & 0.70 & 26.63 & 17.97 \\
\hline $\mathrm{T}_{11}-100 \%$ RDF + B @2 tha $^{-1}$ & 0.86 & 1.03 & 16.16 & 10.96 & 0.34 & 0.43 & 6.36 & 4.59 & 0.61 & 0.68 & 11.36 & 7.23 \\
\hline $\mathrm{T}_{12}-100 \%$ RDF + B@3 tha ${ }^{-1}$ & 0.90 & 1.08 & 26.60 & 18.82 & 0.36 & 0.46 & 10.71 & 8.04 & 0.64 & 0.72 & 18.89 & 12.56 \\
\hline $\mathrm{T}_{13}-100 \%$ RDF + B@ 4 tha ${ }^{-1}$ & 0.93 & 1.12 & 30.98 & 21.97 & 0.37 & 0.48 & 12.38 & 9.54 & 0.66 & 0.74 & 21.92 & 14.49 \\
\hline $\begin{array}{l}\mathrm{T}_{14}-100 \% \text { RDF +B @ } 2 \text { tha }^{-1}+ \\
\text { VC @ } 2.5 \text { tha }^{-1}\end{array}$ & 0.89 & 1.07 & 20.14 & 13.83 & 0.35 & 0.49 & 7.92 & 6.32 & 0.63 & 0.71 & 14.22 & 9.14 \\
\hline $\begin{array}{l}\mathrm{T}_{15} .100 \% \text { RDF + B @ 3 tha }{ }^{-1}+ \\
\text { VC @ } 2.5 \text { tha }^{-1}\end{array}$ & 0.94 & 1.13 & 40.35 & 29.02 & 0.38 & 0.51 & 16.27 & 13.03 & 0.67 & 0.75 & 28.77 & 19.21 \\
\hline $\begin{array}{l}\mathrm{T}_{16}-100 \% \text { RDF + B @ } 4 \text { tha }^{-1}+ \\
\text { VC @ } 2.5 \text { tha }^{-1}\end{array}$ & 0.98 & 1.18 & 51.26 & 37.8 & 0.40 & 0.52 & 20.78 & 16.52 & 0.70 & 0.78 & 36.35 & 24.82 \\
\hline $\mathrm{SE}(\mathrm{m}) \pm$ & 0.04 & 0.05 & 1.37 & 0.98 & 0.01 & 0.02 & 0.59 & 0.47 & 0.03 & 0.03 & 1.03 & 0.62 \\
\hline$C D(p \leq 0.05)$ & 0.13 & 0.15 & 3.97 & 2.83 & 0.04 & 0.07 & 1.71 & 1.37 & 0.09 & 0.1 & 2.97 & 1.8 \\
\hline
\end{tabular}

${ }^{*}$ RDF (Recommended doses of fertilizers), B (Biochar), VC (Vermicompost) 
but it increased significantly over 75\% RDF + biochar and sole application of biochar.

Phosphorus uptake in fruit and haulm of tomato is presented in Table 1. The examination of data reflected that phosphorus uptake in fruit varied from 1.90 to $20.78 \mathrm{~kg} \mathrm{ha}^{-1}$ whereas, in haulm, it ranged from 1.29 to $16.52 \mathrm{~kg} \mathrm{ha}^{-1}$. The highest phosphorus uptake in both fruit and haulm were recorded under $\mathrm{T}_{16}$ with $100 \% \mathrm{RDF}+$ biochar $4 \mathrm{t} \mathrm{ha}^{-1}+$ vermicompost 2.5 whereas least uptake was recorded under control plots. The higher phosphorus concentration and uptake in fruit and haulm of tomato recorded under investigation is possible due to more phosphorus availability to crop through addition of biochar and vermicompost (McDonald et al., 2019; Zhang et al., 2017 and Agegnehu et al., 2015). Chng et al. (2015) also reported an enhanced phosphorus concentration and uptake by the incorporation of biochar and vermicompost. Similarly, Uzoma et al. (2011) and Yamato et al. (2006) concluded an increase in plant available phosphorus in soil with the application of biochar. Moreover, the increased phosphorus availability may also be due to healthy root growth by decreased Al toxicity which causes damage to roots (Aziz et al., 2006).
The least and highest potassium concentration in fruit and haulm was recorded 0.48 and 0.54 and 0.70 and 0.78 , respectively, in control plot and treatment receiving 100\% RDF + biochar 4 t ha $^{-1}+$ vermicompost 2.5 t ha $^{-1} \mathrm{~T}_{16}$ (Table 1). The same trend of potassium concentration was observed in haulm with the lowest value $(0.54 \%)$ in control and the highest value $(0.78 \%)$ in $\mathrm{T}_{16}$. Addition of biochar slightly increased potassium concentration in fruit and haulm with the successive doses of biochar. Following similar pattern, 75\% RDF + biochar nonsignificantly increased potassium concentration in fruit and haulm over sole application of biochar at respective doses. The application of $100 \%$ RDF + biochar slightly increased potassium concentration than $75 \%$ RDF + biochar whereas it showed a significant increase than biochar sole application. The combined application of $75 \%$ RDF + biochar + vermicompost had slightly increased potassium concentration over the application of $75 \%$ RDF + biochar, but it increased significantly over the sole application of biochar. It showed decreased values with respect to potassium concentration than 100\% RDF + biochar. Application of vermicompost in combination with $100 \%$ RDF + biochar again increased potassium concentration slightly over combined application of $75 \%$ RDF + biochar + vermicompost, $75 \%$ RDF +

Table 2 : Impact of biochar as a component of integrated nutrient management on $\mathrm{Fe}, \mathrm{Zn}, \mathrm{Mn}$, and $\mathrm{Cu}$ concentration (ppm) in tomato fruit and haulm dry matter

\begin{tabular}{|c|c|c|c|c|c|c|c|c|}
\hline \multirow[t]{2}{*}{ Treatments } & \multicolumn{2}{|c|}{ Fe concentration } & \multicolumn{2}{|c|}{ Zn concentration } & \multicolumn{2}{|c|}{ Mn concentration } & \multicolumn{2}{|c|}{ Cu concentration } \\
\hline & Fruit & Haulm & Fruit & Haulm & Fruit & Haulm & Fruit & Haulm \\
\hline $\mathrm{T}_{1}-$ Control & 11.29 & 13.70 & 3.07 & 4.21 & 5.93 & 7.91 & 1.71 & 2.83 \\
\hline $\mathrm{T}_{2}-\mathrm{B} @ 2$ tha $^{-1}$ & 12.42 & 15.61 & 3.70 & 4.62 & 7.51 & 9.12 & 2.13 & 3.25 \\
\hline $\mathrm{T}_{3}-\mathrm{B} @ 3$ tha $^{-1}$ & 12.46 & 15.72 & 3.71 & 4.80 & 7.62 & 9.33 & 2.17 & 3.31 \\
\hline $\mathrm{T}_{4}-\mathrm{B} @ 4$ tha $^{-1}$ & 12.75 & 16.62 & 4.04 & 4.81 & 7.68 & 9.62 & 2.23 & 3.42 \\
\hline $\mathrm{T}_{5}-75 \%$ RDF+B @ 2 tha $^{-1}$ & 13.59 & 19.22 & 4.10 & 4.91 & 8.30 & 9.92 & 2.50 & 3.86 \\
\hline $\mathrm{T}_{6}-75 \%$ RDF + B@ 3 tha $^{-1}$ & 13.64 & 20.73 & 4.12 & 4.83 & 8.46 & 10.70 & 2.69 & 3.99 \\
\hline $\mathrm{T}_{7}-75 \% \mathrm{RDF}+\mathrm{B} @ 4$ tha $^{-1}$ & 14.28 & 20.28 & 4.14 & 4.90 & 8.52 & 11.38 & 2.81 & 4.06 \\
\hline $\begin{array}{l}\mathrm{T}_{8}-75 \% \text { RDF + B @ } 2 \text { tha }^{-1}+ \\
\text { VC @ } 2.5 \text { tha }^{-1}\end{array}$ & 27.71 & 36.04 & 7.25 & 8.42 & 14.11 & 15.72 & 5.69 & 6.9 \\
\hline $\begin{array}{l}\mathrm{T}_{9}-75 \% \text { RDF + B @ } 3 \text { tha }^{-1}+ \\
\text { VC @ 2.5 } \text { tha }^{-1}\end{array}$ & 28.58 & 37.38 & 7.32 & 8.43 & 14.32 & 15.81 & 5.72 & 6.97 \\
\hline $\begin{array}{l}\mathrm{T}_{10}-75 \% \mathrm{RDF}+\mathrm{B} @ 4 \text { tha }^{-1}+ \\
\mathrm{VC} @ 2.5 \text { tha }^{-1}\end{array}$ & 29.24 & 37.16 & 7.41 & 8.61 & 15.43 & 16.01 & 5.81 & 7.01 \\
\hline $\mathrm{T}_{11}-100 \%$ RDF + B @2 tha ${ }^{-1}$ & 15.02 & 22.05 & 4.15 & 5.16 & 8.80 & 11.74 & 2.87 & 4.14 \\
\hline $\mathrm{T}_{12}-100 \%$ RDF + B@3 tha ${ }^{-1}$ & 15.09 & 22.23 & 4.18 & 5.27 & 9.01 & 11.98 & 2.92 & 4.21 \\
\hline $\mathrm{T}_{13}-100 \%$ RDF + B@ 4 tha $^{-1}$ & 15.28 & 23.67 & 4.22 & 5.34 & 9.42 & 12.24 & 3.14 & 4.36 \\
\hline $\begin{array}{l}\mathrm{T}_{14}-100 \% \mathrm{RDF}+\mathrm{B} @ 2 \text { tha }^{-1}+ \\
\text { VC @ } 2.5 \text { tha }^{-1}\end{array}$ & 29.65 & 39.25 & 7.51 & 8.50 & 16.41 & 17.62 & 5.87 & 7.14 \\
\hline $\begin{array}{l}\mathrm{T}_{15}-100 \% \text { RDF + B@3 } \text { tha }^{-1}+ \\
\text { VC @ } 2.5 \text { tha }^{-1}\end{array}$ & 29.89 & 41.90 & 7.60 & 8.52 & 16.96 & 17.92 & 5.94 & 7.19 \\
\hline $\begin{array}{l}\mathrm{T}_{16}-100 \% \text { RDF + B@ } 9 \text { tha }^{-1}+ \\
\text { VC@ } 2.5 \text { tha }^{-1}\end{array}$ & 30.15 & 42.62 & 7.70 & 8.61 & 17.39 & 18.35 & 6.12 & 7.24 \\
\hline $\mathrm{SE}(\mathrm{m}) \pm$ & 1.31 & 1.6 & 0.35 & 0.36 & 0.56 & 0.66 & 0.35 & 0.36 \\
\hline$C D(p \leq 0.05)$ & 3.8 & 4.63 & 1.03 & 1.04 & 1.64 & 1.92 & 1.03 & 1.04 \\
\hline
\end{tabular}

*RDF (Recommended doses of fertilizers), B (Biochar), VC (Vermicompost) 
Table 3 : Impact of biochar as a component of integrated nutrient management on $\mathrm{Fe}, \mathrm{Zn}, \mathrm{Mn}$ and Cu uptake $\left(\mathrm{g}\right.$ ha $\left.\mathrm{g}^{-1}\right)$ in tomato fruit and haulm dry matter

\begin{tabular}{|c|c|c|c|c|c|c|c|c|}
\hline \multirow[t]{2}{*}{ Treatments } & \multicolumn{2}{|c|}{ Fe uptake } & \multicolumn{2}{|c|}{ Zn uptake } & \multicolumn{2}{|c|}{ Mn uptake } & \multicolumn{2}{|c|}{ Cu uptake } \\
\hline & Fruit & Haulm & Fruit & Haulm & Fruit & Haulm & Fruit & Haulm \\
\hline $\mathrm{T}_{1}-$ Control & 9.73 & 6.31 & 2.64 & 1.93 & 5.10 & 3.63 & 1.47 & 1.30 \\
\hline$T_{2}-B @ 2$ tha $^{-1}$ & 12.78 & 8.35 & 3.66 & 2.46 & 7.53 & 4.94 & 2.06 & 1.72 \\
\hline $\mathrm{T}_{3}-\mathrm{B} @ 3$ tha $^{-1}$ & 14.06 & 10.01 & 4.24 & 3.01 & 8.65 & 5.80 & 2.51 & 2.08 \\
\hline $\mathrm{T}_{4}-\mathrm{B} @ 4$ tha $^{-1}$ & 16.63 & 12.07 & 5.24 & 3.50 & 10.06 & 7.01 & 2.92 & 2.49 \\
\hline $\mathrm{T}_{5}-75 \%$ RDF + B@2 tha $^{-1}$ & 21.88 & 17.20 & 6.39 & 4.41 & 13.27 & 8.91 & 3.99 & 3.47 \\
\hline $\mathrm{T}_{6}-75 \%$ RDF + B@3 tha ${ }^{-1}$ & 24.31 & 20.89 & 7.33 & 4.83 & 15.73 & 11.20 & 4.79 & 3.99 \\
\hline $\mathrm{T}_{7}-75 \%$ RDF + B@ 4 tha $^{-1}$ & 29.43 & 24.05 & 8.39 & 5.70 & 17.41 & 13.35 & 5.65 & 4.71 \\
\hline $\begin{array}{l}\mathrm{T}_{8}-75 \% \text { RDF + B@ } 2 \text { tha }^{-1}+ \\
\text { VC @ 2.5 tha }\end{array}$ & 56.03 & 41.24 & 14.60 & 9.67 & 41.75 & 27.35 & 11.46 & 7.95 \\
\hline $\begin{array}{l}\mathrm{T}_{9}-75 \% \text { RDF + B @ 3 tha }{ }^{-1}+ \\
\text { VC @ 2.5 tha- }\end{array}$ & 108.19 & 82.85 & 27.53 & 18.73 & 53.77 & 35.16 & 21.51 & 15.54 \\
\hline $\begin{array}{l}\mathrm{T}_{10}-75 \% \text { RDF + B @ } 4 \text { tha }^{-1}+ \\
\text { VC @ } 2.5 \text { tha }^{-1}\end{array}$ & 126.76 & 95.69 & 32.02 & 22.17 & 66.25 & 41.06 & 25.14 & 18.05 \\
\hline $\mathrm{T}_{11}-100 \%$ RDF + B @2 tha ${ }^{-1}$ & 27.74 & 23.49 & 7.89 & 5.56 & 15.54 & 11.66 & 5.51 & 4.48 \\
\hline $\mathrm{T}_{12}-100 \%$ RDF + B@3 tha ${ }^{-1}$ & 44.78 & 38.79 & 12.29 & 9.14 & 17.97 & 13.76 & 8.57 & 7.30 \\
\hline $\mathrm{T}_{13}-100 \%$ RDF + B@ 4 tha $^{-1}$ & 50.71 & 46.42 & 14.04 & 10.49 & 21.41 & 15.80 & 10.43 & 8.56 \\
\hline $\begin{array}{l}\mathrm{T}_{14}-100 \% \mathrm{RDF}+\mathrm{B} @ 2 \text { tha }^{-1}+ \\
\mathrm{VC} @ 2.5 \text { tha }^{-1}\end{array}$ & 66.80 & 50.74 & 16.97 & 10.96 & 54.67 & 32.73 & 13.26 & 9.21 \\
\hline $\begin{array}{l}\mathrm{T}_{15}-100 \% \text { RDF + B @ } 3 \text { tha }^{-1}+ \\
\text { VC @ } 2.5 \text { tha }^{-1}\end{array}$ & 128.60 & 107.41 & 32.60 & 21.77 & 73.60 & 43.69 & 25.48 & 18.42 \\
\hline $\begin{array}{l}\mathrm{T}_{16}-100 \% \mathrm{RDF}+\mathrm{B} @ 4 \text { tha }^{-1}+ \\
\text { VC @ } 2.5 \text { tha }^{-1}\end{array}$ & 155.79 & 136.42 & 40.21 & 27.46 & 90.42 & 55.07 & 31.96 & 23.12 \\
\hline $\mathrm{SE}(\mathrm{m}) \pm$ & 5.78 & 3.87 & 1.08 & 0.74 & 2.47 & 1.66 & 0.93 & 0.66 \\
\hline$C D(p \leq 0.05)$ & 16.7 & 11.18 & 3.11 & 2.15 & 7.14 & 4.79 & 2.71 & 1.91 \\
\hline
\end{tabular}

${ }^{*}$ RDF (Recommended doses of fertilizers), B (Biochar), VC (Vermicompost)

biochar and $100 \%$ RDF + biochar, but it increased significantly over sole application of biochar.

The increase in tissue potassium concentration also resulted due to biochar application could be attributed to the high $\mathrm{K}$ content in the biochar which was reflected by the higher exchangeable K in plots treated biochar (Syuhada et al., 2016; Butnan et al., 2015).

The highest potassium uptake in fruit and haulm of tomato was recorded 36.35 and 24.82 in the treatment receiving $100 \%$ RDF + biochar 4 t ha $^{-1}+$ vermicompost 2.5 t ha $^{-1}\left(T_{16}\right)$ that was significantly higher over all the treatments (Table 1). In contrast to this, control plots exhibited at least potassium uptake in fruit and haulm i.e., 4.14 and 2.49. Potassium uptake increased due to application of biochar over control non-significantly in fruit and haulm. Addition of $75 \%$ RDF with biochar showed a significant increase over biochar alone plots of respective doses. By increasing the dose of RDF to $100 \%$ in combination with biochar resulted in a significant increase in 3 and $4 \mathrm{t} \mathrm{ha}^{-1}$ biochar but at $2 \mathrm{t} \mathrm{ha}^{-1}$ it increased non-significantly over 75\% RDF + biochar whereas it increased significantly over biochar alone plots. Supplying vermicompost in combination with $75 \%$ RDF + biochar had increased potassium uptake significantly over $100 \%$
RDF + biochar @ 3 and 4 t ha ${ }^{-1}, 75 \%$ RDF + biochar and biochar alone. Addition of 100\% RDF + biochar + vermicompost also showed significant increase over 100\% RDF + biochar, 75\% RDF + biochar @ at 3 and 4 t ha $^{-1}$ + vermicompost, 75\% RDF + biochar, and biochar alone plots. Potassium uptake followed similar pattern as nitrogen and phosphorus. The soils amended by biochar increased potassium uptake which might be ascribed to the presence of potassium rich ash in the biochar (Zhang et al., 2017) and Agegnehu et al. (2015). Moreover, biochar has the capacity to increase CEC of soil, thereby the ability of soil increased to hold potassium and make it available for plant uptake (McDonald et al., 2019). Rondon et al. (2007) reported increased potassium uptake by plant biomass in common bean. Similarly, potassium concentration in maize grains also increased with the application of cow manure biochar as reported by Uzoma et al. (2011). Potassium availability increased as soil pH increased by the treating with biochar (Manolikaki and Diamadopoulos, 2016).

The concentration and uptake of micronutrients in fruit and haulm increased as the doses of biochar increased has shown in Table 2 and 3, respectively. Higher nutrient concentration of tomato in biochar and vermicompost treatments might be ascribed to favourable soil chemical and physical 
conditions that might have increased the availability of micronutrients with the application of biochar and vermicompost which has the high organic load. The uptake of micronutrients in fruit and haulm increased as the doses of biochar increased. Jatav et al. (2018) concluded an enhanced micronutrient uptake by the insertion of biochar in the combination of sewage sludge in rice. The higher micronutrient uptake was due to improved fruit and haulm dry matter production by incorporating of biochar in soil as it improves nutrient retention capacity coupled with the beneficial effect of vermicompost. Therefore, increasing doses of biochar application in soil enhanced the sorption of micronutrients and released slowly fulfilling the requirement for tomato plant. Zhang et al. (2017) and Chintala et al. (2013) also delineated that the uptake of micronutrients ( $\mathrm{Fe}, \mathrm{Zn}, \mathrm{Mn}$, and $\mathrm{Cu}$ ) increased in corn plants with the application of biochar.

$\mathrm{pH}$ varied from 5.1 in control to 5.30 (Fig. 6) in the treatment receiving $100 \% \mathrm{RDF}+$ biochar 4 t ha $^{-1}+$ vermicompost $2.5 \mathrm{t} \mathrm{ha}^{-1}\left(\mathrm{~T}_{16}\right)$. It was non-significant with all the treatments. Raison (1979) and Khanna et al. (1994) reported the capacity of ashes to neutralize the acidic soil. Soil pH enhanced on supplying biochar which could be due to alkaline, porous nature and more surface area of biochar which increases the soil cation exchange capacity (Jatav et al., 2018; Warnock et al., 2007). Another cause for increase in soil pH may be high content of calcium carbonate and release of basic cations of biochar (Chintala et al., 2014; McDonald et al., 2019). However, decrease in $\mathrm{pH}$ in some treatments, may be due to the acidifying nature of ammonium nitrate fertilizer, as a result product of proton-generating reaction of ammonium ions (McDonald et al., 2019) and also it may cause due to N nitrification after urea and NPK were added (Chathurika, et al., 2016; Syuhada et al., 2016; Zhu et al. 2014).

The data pertaining to electrical conductivity of postharvest soil as influenced by biochar as a component of integrated nutrient management is given in Table 4. The lowest EC recorded was $0.39 \mathrm{dS} \mathrm{m}^{-1}$ with $100 \% \mathrm{RDF}+$ biochar $4 \mathrm{t} \mathrm{ha}^{-1}+$ vermicompost 2.5 tha $^{-1}$ application which increased by 0.07 units in the treatment receiving $100 \% \mathrm{RDF}+$ biochar $2 \mathrm{t} \mathrm{ha}^{-1}+$ vermicompost $2.5 \mathrm{t} \mathrm{ha}^{-1}, 100 \% \mathrm{RDF}+$ biochar $2 \mathrm{t} \mathrm{ha}^{-1}$ and $75 \%$ $\mathrm{RDF}+$ biochar 2 tha $^{-1}$ giving highest value of $0.46 \mathrm{dS} \mathrm{m}^{-1}$. This was also observed to be at par over all other treatments corroborating the previous findings (Obour et al., 2020; Usman et al., 2016; Agegnehu et al., 2015; Cely et al., 2015).

The bulk density varied non-significantly from 1.33 to $1.44 \mathrm{~g} \mathrm{cc}^{-1}$ (Table 4). The highest bulk density 1.44 was recorded in control plots and it decreased on applying biochar and

Table 4 : Impact of biochar as a component of integrated nutrient management on soil $\mathrm{EC}\left(\mathrm{dS} \mathrm{m}^{-1}\right)$, bulk density $\left(\mathrm{g} \mathrm{cc}^{-1}\right)$, available $\mathrm{N}, \mathrm{P}$ and $\mathrm{K}\left(\mathrm{kg} \mathrm{ha}^{-1}\right)$ and available $\mathrm{Fe}, \mathrm{Zn}, \mathrm{Mn}$ and $\mathrm{Cu}\left(\mathrm{mg} \mathrm{kg}^{-1}\right)$ after harvest of tomato crop.

\begin{tabular}{|c|c|c|c|c|c|c|c|c|c|}
\hline Treatments & EC & $\begin{array}{l}\text { Bulk } \\
\text { density }\end{array}$ & $\begin{array}{l}\text { Available } \\
\mathrm{N}\end{array}$ & $\begin{array}{l}\text { Available } \\
\text { P }\end{array}$ & $\begin{array}{l}\text { Available } \\
\mathrm{K}\end{array}$ & $\begin{array}{l}\text { Available } \\
\text { Fe }\end{array}$ & $\begin{array}{l}\text { Available } \\
\text { Zn }\end{array}$ & $\begin{array}{l}\text { Available } \\
\text { Mn }\end{array}$ & $\begin{array}{l}\text { Available } \\
\mathrm{Cu}\end{array}$ \\
\hline $\mathrm{T}_{1}-$ Control & 0.45 & 1.44 & 221.13 & 12.35 & 215.16 & 5.70 & 32.16 & 43.67 & 14.62 \\
\hline $\mathrm{T}_{2}-\mathrm{B} @ 2$ tha $^{-1}$ & 0.44 & 1.38 & 227.65 & 13.67 & 219.19 & 6.01 & 32.21 & 43.73 & 14.64 \\
\hline $\mathrm{T}_{3}-\mathrm{B} @ 3$ tha $^{-1}$ & 0.42 & 1.34 & 231.71 & 14.83 & 221.22 & 6.12 & 32.25 & 43.79 & 14.66 \\
\hline $\mathrm{T}_{4}-\mathrm{B} @ 4$ tha $^{-1}$ & 0.41 & 1.32 & 234.13 & 15.76 & 222.98 & 6.18 & 32.27 & 43.81 & 14.67 \\
\hline $\mathrm{T}_{5}-75 \%$ RDF + B @2 tha ${ }^{-1}$ & 0.46 & 1.41 & 242.45 & 17.44 & 227.65 & 6.21 & 33.46 & 45.43 & 15.21 \\
\hline $\mathrm{T}_{6}-75 \%$ RDF + B@3 tha ${ }^{-1}$ & 0.45 & 1.36 & 249.12 & 19.14 & 230.06 & 6.33 & 33.47 & 45.44 & 15.21 \\
\hline $\mathrm{T}_{7}-75 \%$ RDF + B@ 4 tha $^{-1}$ & 0.43 & 1.33 & 254.60 & 20.64 & 232.81 & 6.45 & 33.49 & 45.47 & 15.22 \\
\hline $\begin{array}{l}\mathrm{T}_{8}-75 \% \text { RDF + B @ } 2 \text { tha }^{-1}+ \\
\text { VC @ 2.5 tha }{ }^{-1}\end{array}$ & 0.44 & 1.39 & 247.13 & 25.27 & 230.84 & 6.81 & 36.28 & 49.26 & 16.49 \\
\hline $\begin{array}{l}\mathrm{T}_{9}-75 \% \text { RDF + B@3 } \text { tha }^{-1}+ \\
\text { VC@ } 2.5 \text { tha }^{-1}\end{array}$ & 0.43 & 1.34 & 258.33 & 27.39 & 234.54 & 6.90 & 36.34 & 49.34 & 16.18 \\
\hline $\begin{array}{l}T_{10}-75 \% \text { RDF + B @ } 4 \text { tha }^{-1}+ \\
\text { VC @ } 2.5 \text { tha }^{-1}\end{array}$ & 0.42 & 1.30 & 266.67 & 27.86 & 237.51 & 7.02 & 36.53 & 49.60 & 16.60 \\
\hline $\mathrm{T}_{11}-100 \%$ RDF + B@ 2 tha $^{-1}$ & 0.46 & 1.43 & 245.75 & 20.85 & 229.15 & 6.28 & 33.49 & 45.47 & 15.22 \\
\hline $\mathrm{T}_{12}-100 \% \mathrm{RDF}+\mathrm{B} @ 3 \mathrm{tha}^{-1}$ & 0.44 & 1.37 & 254.13 & 22.07 & 232.78 & 6.39 & 33.50 & 45.48 & 15.22 \\
\hline $\mathrm{T}_{13}-100 \%$ RDF + B @ 4 tha $^{-1}$ & 0.42 & 1.34 & 261.13 & 23.41 & 234.93 & 6.48 & 33.51 & 45.50 & 15.23 \\
\hline $\begin{array}{l}T_{14}-100 \% \text { RDF + B @ } 2 \text { tha }^{-1}+ \\
\text { VC @ 2.5 tha }{ }^{-1}\end{array}$ & 0.46 & 1.40 & 251.21 & 28.15 & 236.29 & 6.85 & 36.55 & 49.63 & 16.61 \\
\hline $\begin{array}{l}T_{15}-100 \% \text { RDF + B @ 3 tha }{ }^{-1}+ \\
\text { VC @ 2.5 tha }{ }^{-1}\end{array}$ & 0.42 & 1.35 & 266.62 & 30.34 & 240.62 & 6.94 & 36.58 & 49.67 & 16.62 \\
\hline $\begin{array}{l}\mathrm{T}_{16}-100 \% \text { RDF + B @ } 4 \text { tha }^{-1}+ \\
\text { VC @ } 2.5 \text { tha }^{-1}\end{array}$ & 0.39 & 1.33 & 277.13 & 31.35 & 243.08 & 7.05 & 36.61 & 49.71 & 16.64 \\
\hline $\mathrm{SE}(\mathrm{m}) \pm$ & 0.02 & 0.07 & 5.63 & 1.24 & 4.94 & 0.27 & 0.84 & 0.95 & 0.89 \\
\hline$C D(p \leq 0.05)$ & NS & NS & 16.27 & 3.59 & 14.28 & 0.79 & 2.43 & 2.74 & NS \\
\hline
\end{tabular}

${ }^{*} \mathrm{RDF}$ (Recommended doses of fertilizers), B (Biochar), VC (Vermicompost) 
vermicompost. The application of $100 \%$ RDF + biochar $4 \mathrm{t} \mathrm{ha}^{-1}+$ vermicompost $2.5 \mathrm{t} \mathrm{ha}^{-1}$ recorded lowest bulk density $\left(1.33 \mathrm{~g} \mathrm{cc}^{-1}\right)$. The minimum bulk density on adding biochar as well as vermicompost. It might be decreased because biochar possess low bulk density.

The highest nitrogen, phosphorus and potassium content was recorded in the treatment receiving 100\% RDF + biochar $4 \mathrm{t}$ $\mathrm{ha}^{-1}+$ vermicompost 2.5 tha $^{-1}$. It increased from initial soil $\mathrm{N}$ status by $6 \%$ and $25 \%$ over control, from initial soil $P$ status by 67 and $153 \%$ over control and from initial soil $\mathrm{K}$ status by 3 and $12 \%$ over control. Agegnehu et al. (2015) reported increase in N, P and K content in soil after harvest of maize. This may be owing to $\mathrm{N}$ immobilization and decreased loss of $\mathrm{N}$ by leaching in the presence of recalcitrant biochar materials (Rondon et al., 2007). Biochar has the ability to act as a slow release $\mathrm{N}$ fertilizer, so availability of nitrogen increased (Chan and Xu, 2009; Steiner et al., 2008). An increase in soil pH and CEC, which reduces the activity of $\mathrm{Fe}$ and $\mathrm{Al}$, can also contribute to higher values of available nutrients in soils treated with biochar (McDonald et al., (2019). The available P content enhanced due to high porous nature of biochar which provides favourable environment for mycorrhizal fungi. It make unavailable phosphorus available to plants by secreting P-solubilizing organic acid (Chathurika, et al., 2016; Gul and Whalen, 2016; Warnock et al., 2007). An experiment was also conducted by Uzoma et al., (2011) on maize by application of cow manure biochar and reported increase in $\mathrm{P}$ availability as a result of enhanced in soil pH. Similarly, the application of biochar increase the CEC of soil thereby increasing the capability of soil to hold $\mathrm{K}$. The availability of $\mathrm{K}$ in soil might be increased by enhancing $\mathrm{pH}$ of soil by application of biochar as increase in $\mathrm{pH}$ of soil may force the strongly attached $\mathrm{K}$ on clay particles and pulled into the soil solution (McDonald et al., 2019; Manolikaki and Diamadopoulos, 2016; Smider and Singh, 2014).

There was improvement in the content of $\mathrm{Fe}, \mathrm{Zn}, \mathrm{Mn}$ and $\mathrm{Cu}$ (Table 4) with the application of biochar. The content of Fe, Zn, $\mathrm{Mn}$ and Cu varied from 5.7 to $7.05,32.16$ to $36.61,43.67$ to 49.71 and 14.62 to $16.64 \mathrm{~g} \mathrm{ha}^{-1}$, respectively. The maximum content of $\mathrm{Fe}, \mathrm{Zn}, \mathrm{Mn}$ and $\mathrm{Cu}$ was filed with the application of $100 \% \mathrm{RDF}+$ biochar 4 t/ha + vermicompost 2.5 t/ha whereas the lowest contents were recorded in control, however, the $\mathrm{Cu}$ content showed non-significant increase. The increase in micronutrients availability may be due to supply of sufficient amount Fe, Zn, Mn and $\mathrm{Cu}$ through vermicompost resulting in enhanced availability of $\mathrm{Fe}, \mathrm{Zn}, \mathrm{Mn}$ and $\mathrm{Cu}$ by mineralization of organic matter and release during decomposition of vermicompost (Jatav et al., 2018; Prasanna, 2012).

The data pertaining to exchangeable acidity, exchangeable aluminium and acid saturation is shown in Fig. 1, 2

3.5

Exchangeable acidity $\left(\mathrm{cmol}(\mathrm{p}+) \mathrm{kg}^{-1}\right)$

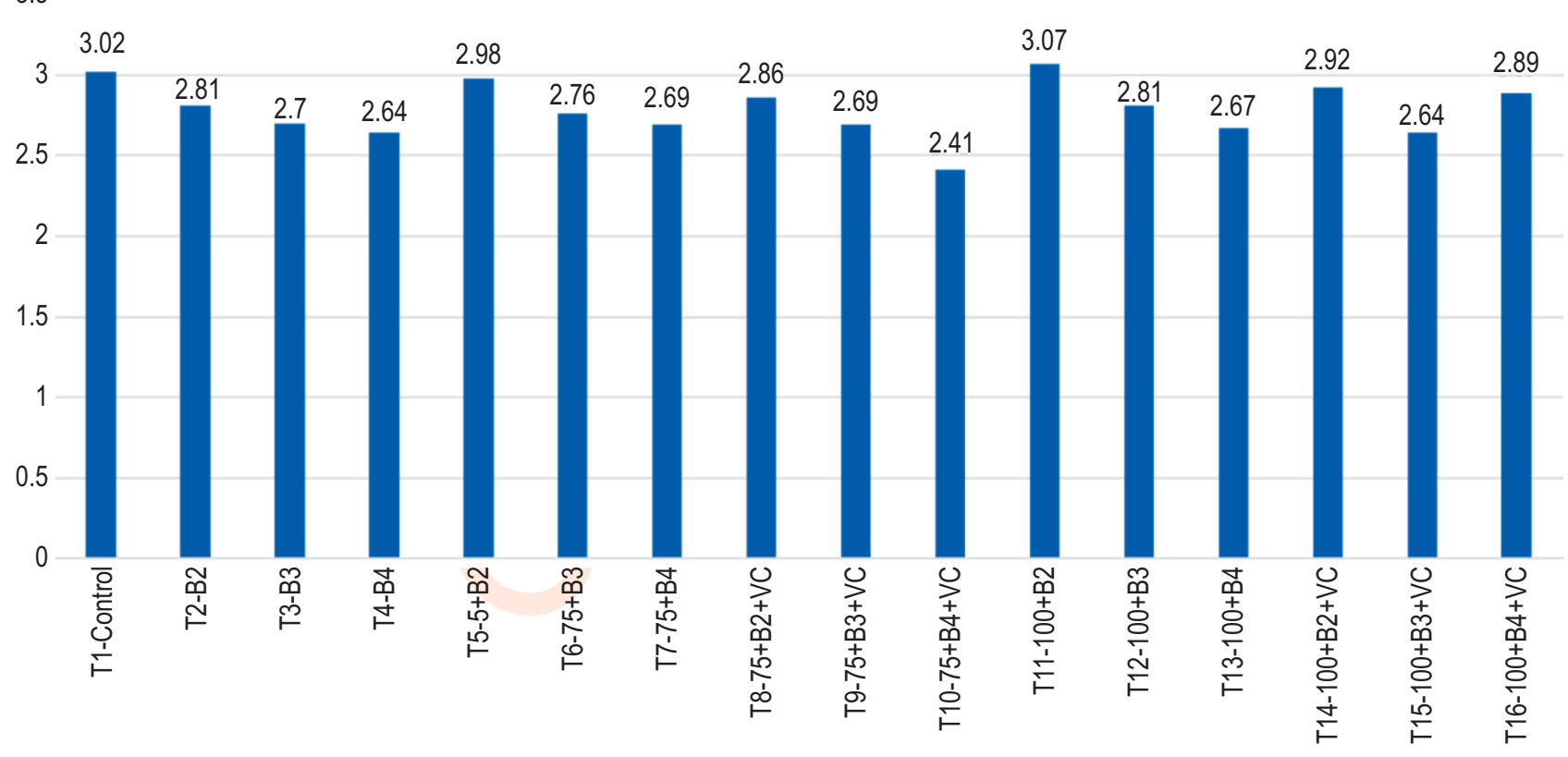

Fig. 1 : Impact of biochar as a component of integrated nutrient management on exchangeable acidity $\left(\mathrm{cmol}(\mathrm{p}+) \mathrm{kg}^{-1}\right)$ after harvest of tomato crop. T1 -

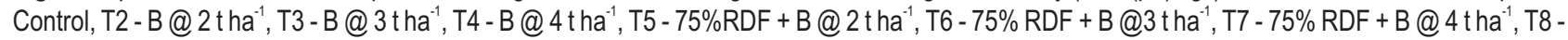
$75 \% R D F+B @ 2 t^{-1}+V C @ 2.5 t^{-1} a^{-1}, T 9-75 \% R D F+B @ 3 t h a^{-1}+V C @ 2.5 t^{-1} a^{-1}, T 10-75 \% R D F+B @ 4$ tha ${ }^{-1}+V C @ 2.5 t^{-1} a^{-1}, T 11-100 \%$ RDF +B @ 2 tha $^{-1}, T 12-100 \%$ RDF + B @ 3 tha ${ }^{-1}, T 13-100 \% R D F+B @ 4$ tha $^{-1}, T 14-100 \% R D F+B @ 2 t^{-1}+V C @ 2.5$ tha ${ }^{-1}, T 15100 \% R D F+B @ 3$ tha ${ }^{-1}+$ VC @ $2.5 \mathrm{t} \mathrm{ha}^{-1}, \mathrm{~T} 16-100 \%$ RDF + B @ 4 tha ${ }^{-1}+\mathrm{VC} @ 2.5 \mathrm{t} \mathrm{ha}^{-1}$. *RDF (Recommended doses of fertilizers), B (Biochar), VC (Vermicompost). CD ( $\mathrm{p} \leq$ $0.05)$ : NS (Non-significant). 


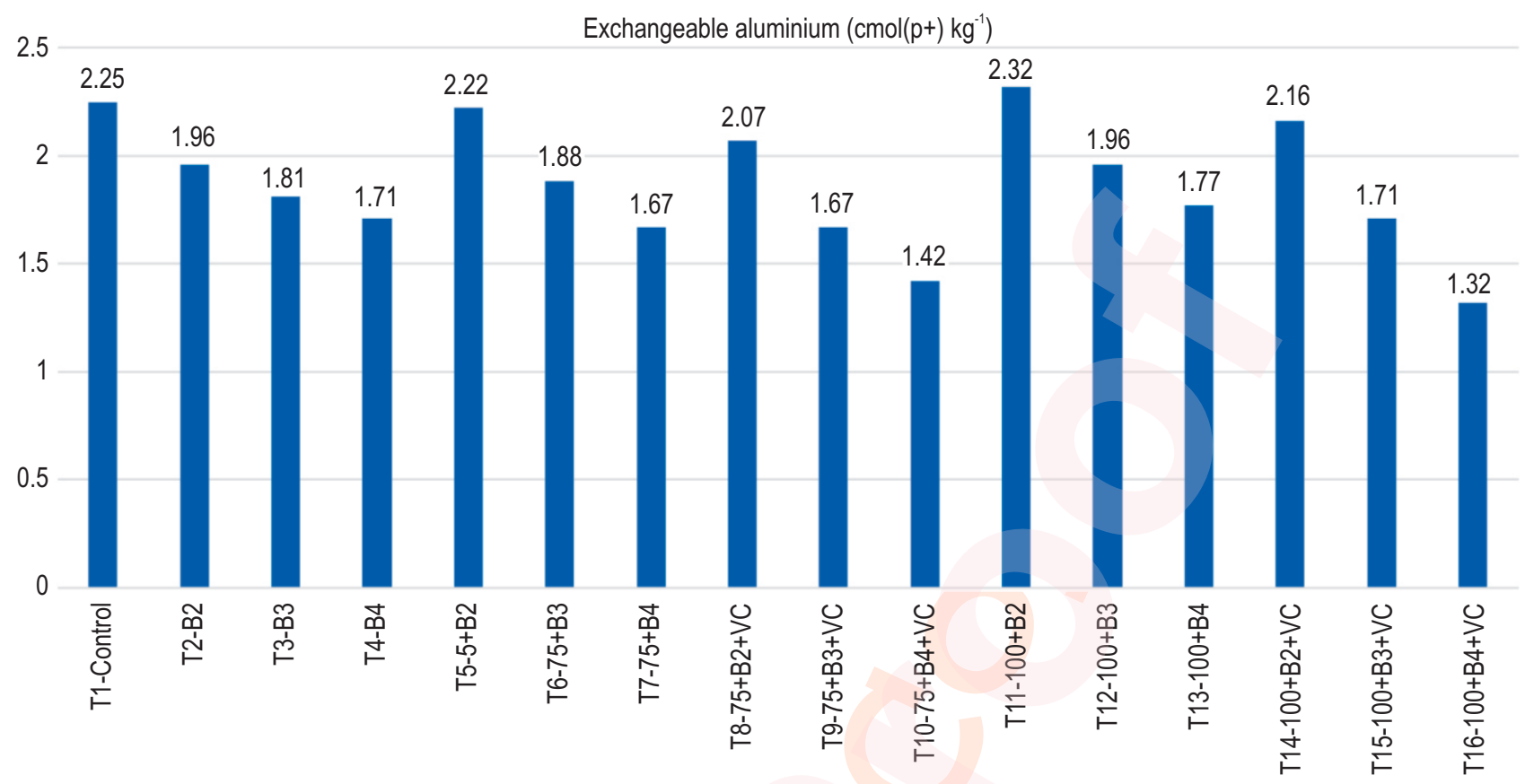

Fig. 2 : Impact of biochar as a component of integrated nutrient management on exchangeable aluminium $\left(\mathrm{cmol}(\mathrm{p}+) \mathrm{kg}^{-1}\right.$ after harvest of tomato crop. T1

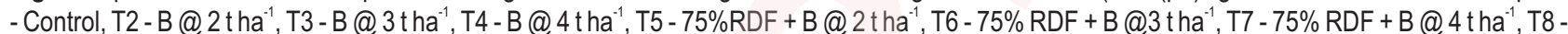
$75 \% R D F+B @ 2 t^{-1}+V C @ 2.5$ tha $^{-1}, T 9-75 \% R D F+B @ 3 t^{-1}+V C @ 2.5$ tha $^{-1}, T 10-75 \% R D F+B @ 4$ tha ${ }^{-1}+V C @ 2.5$ tha ${ }^{-1}, T 11-100 \%$ RDF + B

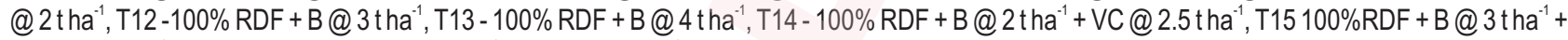
VC @ 2.5 t ha ${ }^{-1}, T 16-100 \%$ RDF + B @ 4 t ha ${ }^{-1}+$ VC @ 2.5 t ha $^{-1}$. *RDF (Recommended doses of fertilizers), B (Biochar), VC (Vermicompost). CD ( $p \leq$ 0.05): NS (Non-significant).

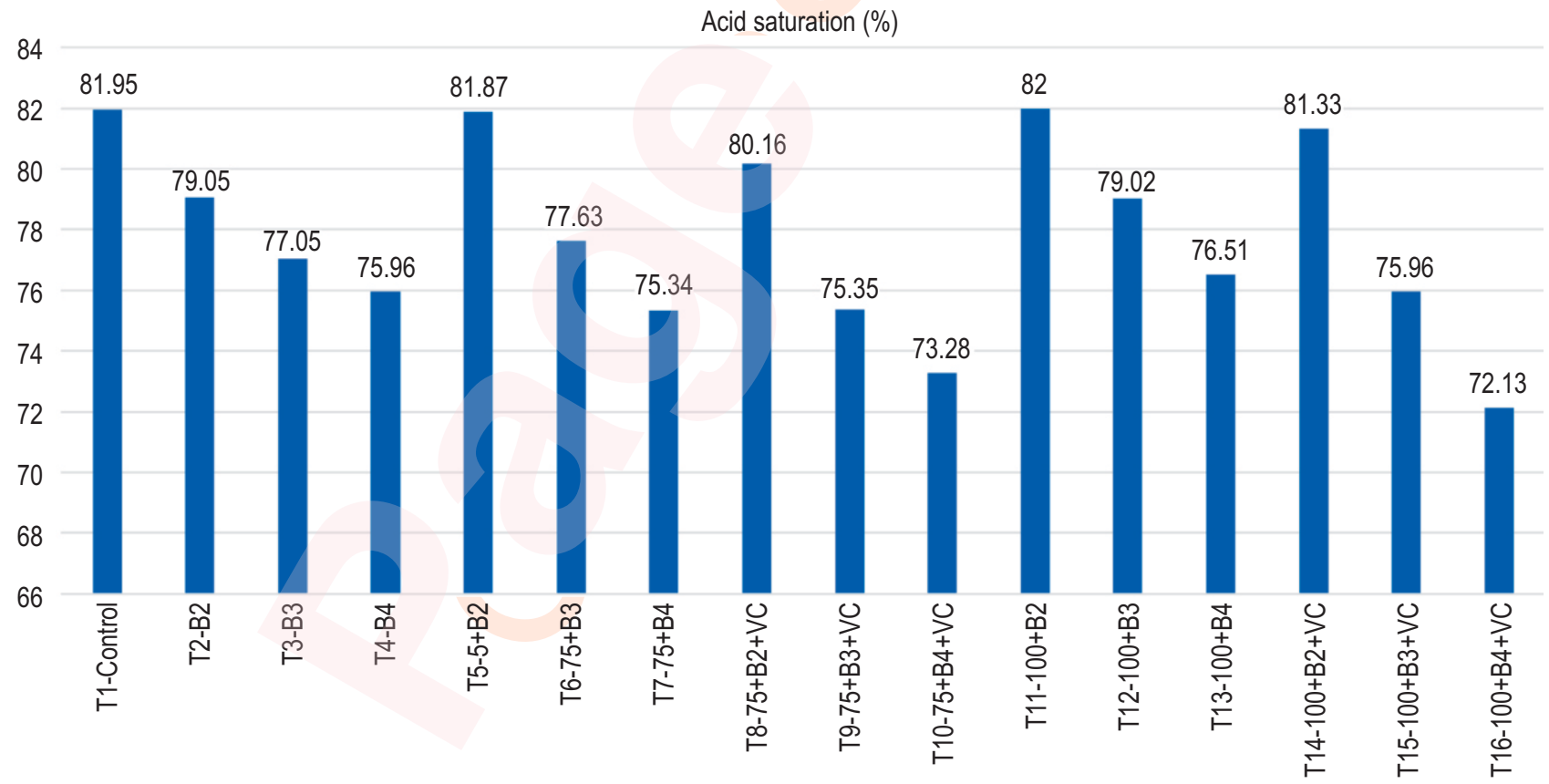

Fig. 3 : Impact of biochar as a component of integrated nutrient management on acid saturation (\%) after harvest of tomato crop. T1 - Control, T2 - B @ $2 \mathrm{t}$

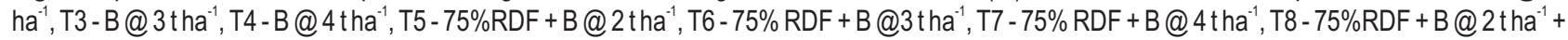

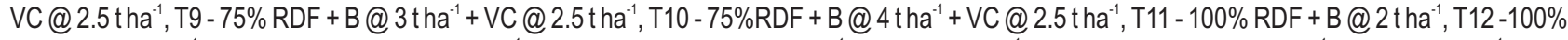

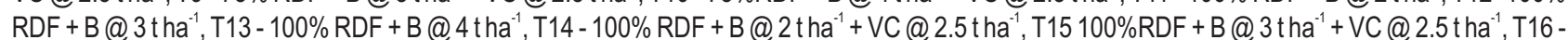
$100 \%$ RDF + B @ 4 t ha ${ }^{-1}$ + VC @ 2.5 t ha $a^{-1}$. RDF (Recommended doses of fertilizers), B (Biochar), VC (Vermicompost). CD ( $\left.p \leq 0.05\right)$ : NS (Nonsignificant). 
2.5 Exchangeable $\mathrm{Ca}^{2+}$ and $\mathrm{Mg}^{2+}\left(\mathrm{cmol}(\mathrm{p}+) \mathrm{kg}^{-1}\right)$

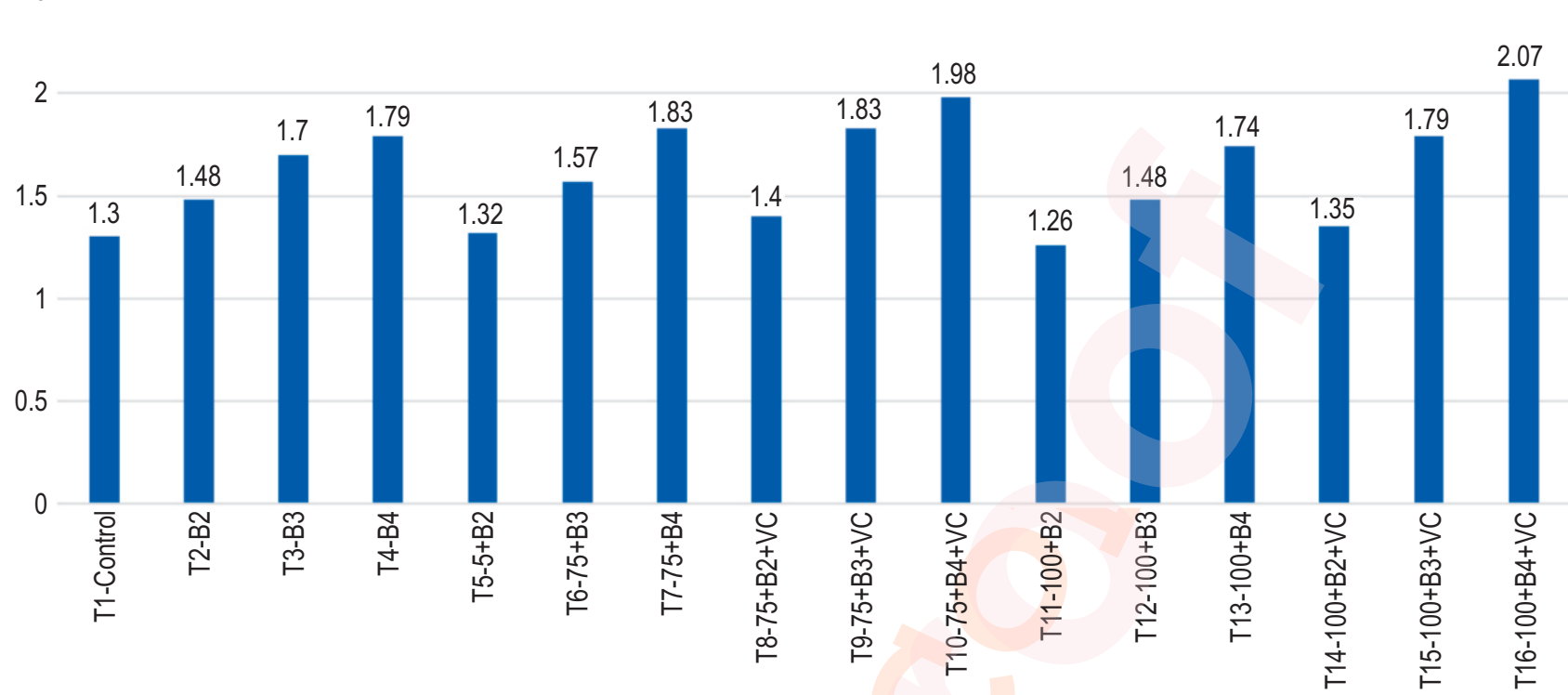

Fig. 4 : Impact of biochar as a component of integrated nutrient management on exchangeable $\mathrm{Ca}^{2+}$ and $\mathrm{Mg}^{2+}\left(\mathrm{cmol}(\mathrm{p}+) \mathrm{kg}^{-1}\right)$ after harvest of tomato crop.

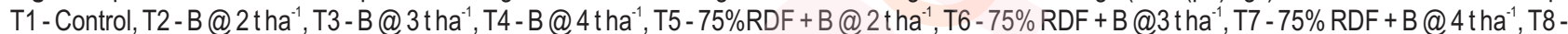
$75 \% R D F+B @ 2$ tha $^{-1}+V C @ 2.5$ tha $^{-1}, T 9-75 \% R D F+B @ 3$ tha $^{-1}+V C @ 2.5$ tha $^{-1}, T 10-75 \% R D F+B @ 4$ tha ${ }^{-1}+V C @ 2.5$ tha ${ }^{-1}, T 11-100 \%$ RDF + B @2 tha ${ }^{-1}, T 12-100 \%$ RDF + B @ 3 tha ${ }^{-1}, T 13-100 \%$ RDF + B @ 4 tha $^{-1}$, T14 - 100\% RDF + B @ 2 tha $^{-1}+$ VC @ 2.5 tha $a^{-1}, T 15$ 100\%RDF + B @ 3 tha ${ }^{-1}+$

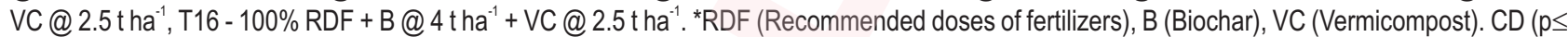
0.05): NS (Non-significant).

5.35

$\mathrm{pH}$

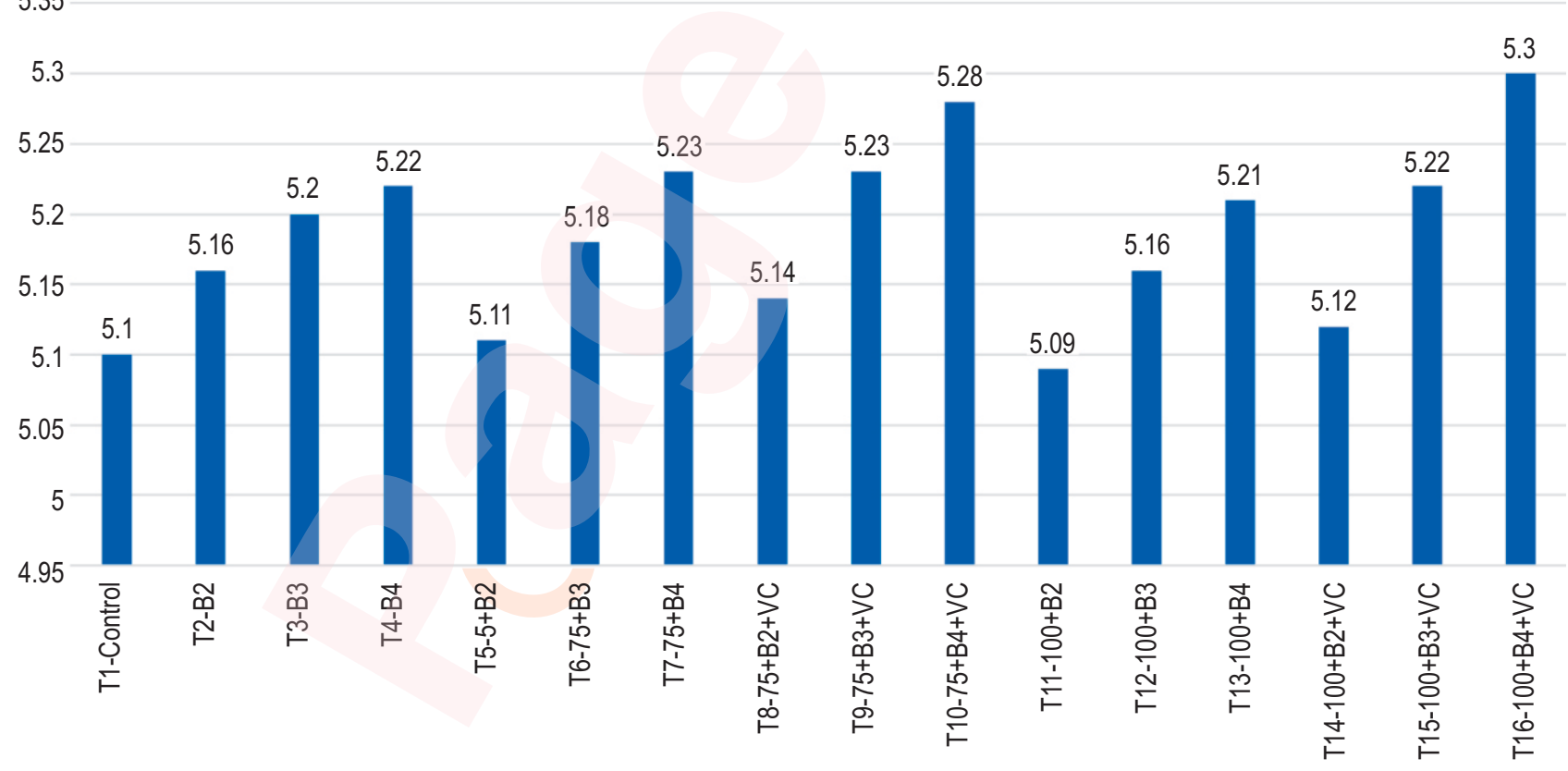

Fig. 6 : Impact of biochar as a component of integrated nutrient management on $\mathrm{pH}$ after harvest of tomato crop. T1 - Control, T2 - B @ 2 tha- ${ }^{-1}, \mathrm{~T} 3$ - B @ $3 \mathrm{t}$

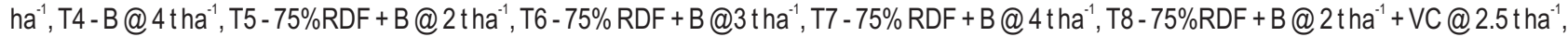
T9-75\% RDF+B @ 3 tha $^{-1}+V C @ 2.5$ tha $^{-1}, T 10-75 \% R D F+B @ 4$ tha ${ }^{-1}+V C @ 2.5$ tha $^{-1}, T 11-100 \% R D F+B @ 2 t^{-1} a^{-1}, T 12-100 \%$ RDF + B @ 3 tha ${ }^{-1}$, T13-100\% RDF+B @ 4 tha $^{-1}, T 14-100 \%$ RDF + B @ 2 tha ${ }^{-1}+V C @ 2.5$ tha $^{-1}, T 15100 \% R D F+B @ 3$ tha ${ }^{-1}+V C @ 2.5$ tha $a^{-1}, T 16-100 \%$ RDF + B @ 4 t $h^{-1}+V C @ 2.5$ tha $^{-1} .{ }^{*} R D F$ (Recommended doses of fertilizers), B (Biochar), VC (Vermicompost). CD ( $\left.\leq \leq 0.05\right)$ : NS (Non-significant). 


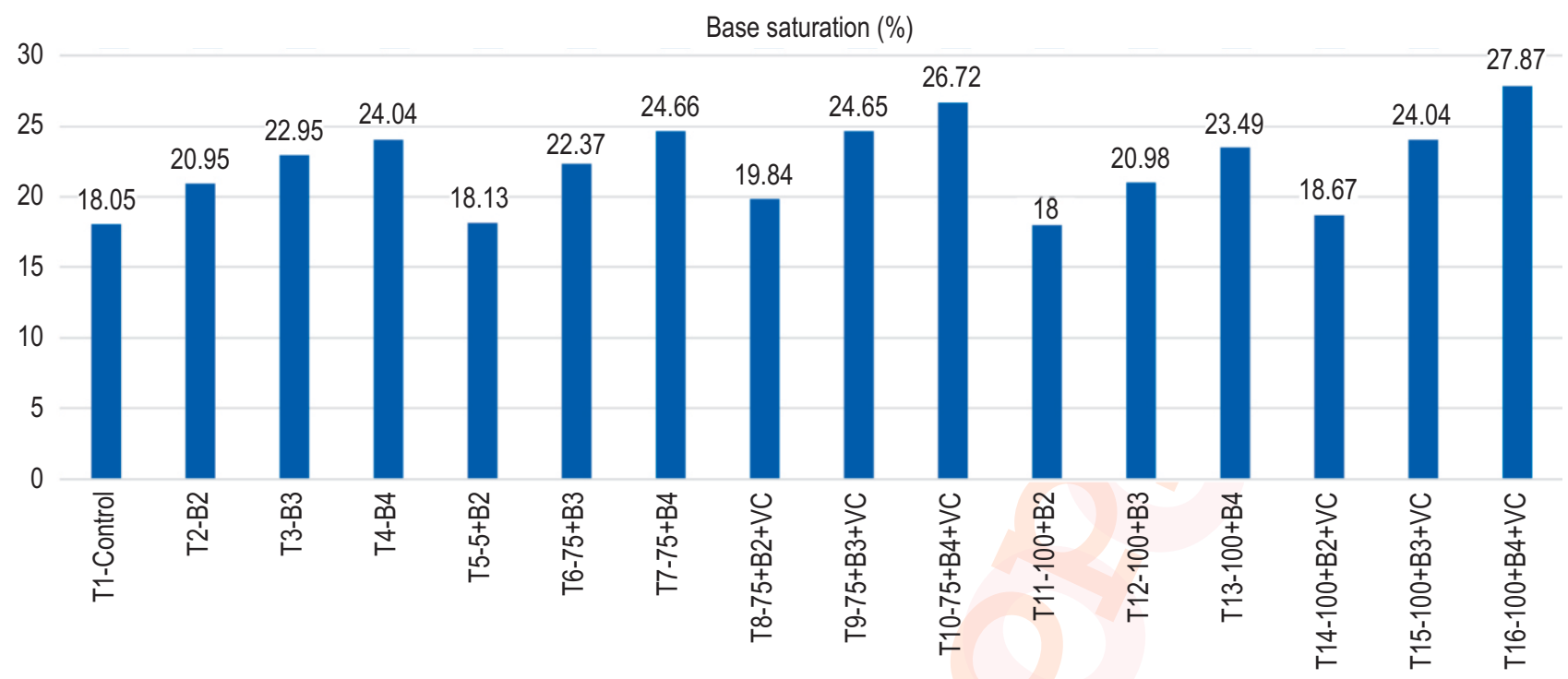

Fig. 5 : Impact of biochar as a component of integrated nutrient management on base saturation (\%) after harvest of tomato crop. T1 - Control, T2 - B @ 2

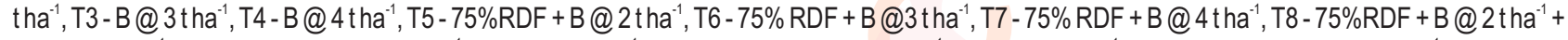
VC@ 2.5 tha $^{-1}$, T9 - 75\% RDF + B @ 3 tha ${ }^{-1}+V C @ 2.5$ tha $^{-1}, T 10-75 \% R D F+B @ 4$ tha ${ }^{-1}+V C @ 2.5$ t ha ${ }^{-1}, T 11-100 \%$ RDF + B @ 2 tha ${ }^{-1}, T 12-100 \%$

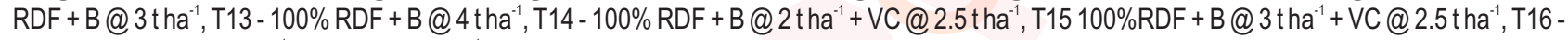
$100 \%$ RDF + B @ 4 t ha ${ }^{-1}+$ VC @ 2.5 t ha $^{-1} .{ }^{*}$ RDF (Recommended doses of fertilizers), B (Biochar), VC (Vermicompost). CD ( $\left.\leq \leq 0.05\right)$ : NS (Nonsignificant).

and 3 The influence of biochar on exchangeable acidity of postharvest soil as a constituent of integrated nutrient management showed statistically non-significant results between treatments, but exchangeable aluminium recorded significant statistically among the treatments. However, the lowest exchangeable acidity and aluminium was documented with the application of $100 \%$ $\mathrm{RDF}+$ biochar 4 tha $\mathrm{a}^{-1}+$ vermicompost 2.5 tha $^{-1}$. This may be due to the fact that organic manure and biochar have ability to consume protons which reduce the acidity. Soil application of biochar can reduce $\mathrm{Al}$ concentration either due to decrease in exchangeable Al through adsorption on the surfaces of negatively charged biochar or reduction of $\mathrm{Al}$ activity in soil solution through chelation with soluble organic compounds from the biochar (Syuhada et al., 2016; Butnan et al., 2015: Hati et al., 2008). The exchangeable aluminium decreased due to increase in soil pH (Syuhada et al., 2016; Opala et al., 2012; Narambuye and Haynes, 2006). Similar trend was observed in exchangeable acidity and exchangeable aluminium for acid saturation.

The highest exchangeable $\mathrm{Ca}^{2+}+\mathrm{Mg}^{2+}$ was recorded $\left(2.07 \mathrm{cmol}(\mathrm{p}+) \mathrm{kg}^{-1}\right)$ in the treatment receiving 100\% RDF + biochar 4 tha $^{-1}+$ vermicompost 2.5 tha ${ }^{-1}\left(\right.$ Fig. 4). However, $\mathrm{Ca}^{2+}+$ $\mathrm{Mg}^{2+}$ showed increase with application of biochar and vermicompost, which may be due to increase in soil pH that leads to enhance formation of organic anions during decomposition of organic matter (McDonald et al., 2019; Butnan et al., 2015; Narambuye and Haynes, 2006) which consumed acidity causing protons (Haynes and Mokolobate, 2001) and solubilise inherent $\mathrm{Ca}$ and $\mathrm{Mg}$ ions content present in the organic matter. Application of biochar and vermicompost improved the soil physical condition which provided suitable environment for microbiological activity which improved mineralization and increased the content of exchangeable $\mathrm{Ca}^{2+}+\mathrm{Mg}^{2+}$ (Syuhada et al., 2016; Agegnehu et al., (2015) and Uzoma et al., 2011). Similar trends were observed for base saturation as observed in exchangeable $\mathrm{Ca}^{2+}+\mathrm{Mg}^{2+}$ (Fig. 5).

Based on the findings of above investigation it may be concluded that biochar is an effective component of integrated nutrient management under acidic soil condition. The application of biochar @ $4 \mathrm{t} \mathrm{ha}^{-1}$ in combination with 100\% RDF + vermicompost @ $2.5 \mathrm{t} \mathrm{ha}{ }^{-1}$ may be recommended as most appropriate combination for increase in tomato productivity and improving health of acidic soil in Meghalaya.

\section{References}

Agegnehu, G., M.I. Bird, P.N. Nelson and A.M. Bass: The ameliorating effects of biochar and compost on soil quality and plant growth on a Ferralsol. Soil Res., 53, 1-12 (2015).

Aziz, T., M.A. Rahmatullah, M. Maqsood, I. Tahir and M.A. Cheema: Phosphorus utilization by six Brassica cultivars (Brassica juncea L.) from tri-calcium phosphate; a relatively insoluble $\mathrm{P}$ compound. Pak. J. Bot., 38, 1529-1538 (2006).

Bray, R.H. and L.T. Kurtz: Determination of total organic and available forms of phosphorus in soils. Soil Sci., 59, 39-45 (1945).

Butnan, S., J.L. Deenik, B. Toomsan, M.J. Antal and P. Vityakona: Biochar characteristics and application rates affecting corn growth and properties of soils contrasting in texture and mineralogy. Geoderma, 237, 105-116 (2015). 
Campbell, D.J. and J.K. Henshall: Bulk density. In: Soil and Environmental Analysis: Physical Methods (Eds.: K.A. Smith and C.M. Mullins). $2^{\text {nd }}$ Edn., Dekker, New York, pp. 315-348 (2001).

Cely, P., G. Gasco, P.J. Ferreiro and A. Mendez: Agronomic properties of biochars from different manure wastes. J. Anal. Appl. Pyrol., 111, 173-182(2015).

Chan, K.Y. and Z. Xu: Biochar: Nutrient properties and their enhancement. In: Biochar for Environmental Management: Science and Technology (Eds.: J. Lehmann, and S. Joseph). Earthscan, London, pp. 67-84 (2009).

Chan, K.Y., V.L. Zwiteten, I. Meszaros, A. Downie and S. Joseph: Using poultry litter biochars as soil amendments. Aust. J. Soil Res., 46, 437-444 (2008).

Chathurika, J.A.S., D. Kumaragamage, F. Zvomuya, O.O. Akinremi, D.N. Flaten, S.P. Indraratne and W.S. Dandeniya: Woodchip biochar with or without synthetic fertilizers affects soil properties and available phosphorus in two alkaline, chernozemic soils. Can. J. Soil Sci., 96, 472-484 (2016).

Chintala, R., R.H. Gelderman, T.E. Schumacher and D. Malo: Vegetative corn growth and nutrient uptake in biochar amended soils from an eroded landscape. Conference: Joint Annual Meeting of the Association for the Advancement of Industrial Crops and the USDA National Institute of Food and Agriculture at Washington D.C. pp. 1-485 (2014).

Chintala, R., J. Mollinedo, T.E. Schumacher, D.D. Malo and J.L. Julson: Effect of biochar on chemical properties of acidic soil. Arch. Agron. Soil Sci., 60, 393-404 (2013).

Chng, H.Y., O.H. Ahmed and N.M.A. Majid: Improving phosphorus availability, nutrient uptake and dry matter production of Zea mays L. on a tropical acid soil using poultry manure biochar and pineapple leaves compost. Expl. Agric., 52, 447-465 (2015).

CRIDA, Annual Report 2011-12, Central Research Institute for Dryland Agriculture, Hyderabad, India. pp. 178 (2012).

Demirbas, A.: Effects of temperature and particle size on biochar yield from pyrolysis of agricultural residues. J. Anal. Appl. Pyrolysis., 72, 243-248 (2004).

Fageria, N.K.: Optimum soil acidity indices for dry bean production on an oxisol in no-tillage system. Commun. Soil. Sci. PlantAnal., 39, 845$857(2008)$

Gaunt, J. and A. Cowie: Biochar greenhouse gas accounting and emission trading. In: Biochar for Environmental Management: Science and Technology (Eds.: J. Lehmann, and S. Joseph). Earthscan, London, pp: 317-340 (2009).

Glaser, B., J. Lehmann and W. Zech:Ameliorating physical and chemical properties of highly weathered soils in the tropics with charcoal -A review. Biol. Ferti. Soils., 35, 219-230 (2002).

Gomez, K.A. and A.A. Gomez: Statistical Procedures for Agricultural Research. $2^{\text {nd }}$ Edn., John Wiley and Sons, New York (1984).

Gul, S. and J.K. Whalen: Biochemical cycling of nitrogen and phosphorus in biochar-amended soils. Soil Bio. Biochem., 103, 1-15(2016).

Hati, K.M., A. Swarup, B. Mishra, M.C. Manna, R.H. Wanjari, K.G. Mandal and A.K. Misra: Impact of long-term application of fertilizer, manure and lime under intensive cropping on physical properties and organic carbon content of an Alfisol. Geoderma, 148, 173-179 (2008).

Haynes, R.J. and M.S. Mokolobate: Amelioration of Al toxicity and P deûciency in acid soils by additions of organic residues: A critical review of the phenomenon and the mechanism involved. Nut. Cycl. Agro-eco., 59, 47-63 (2001).
Jackson, M.L.: Soil Chemical Analysis. Prentice Hall of India, New Delhi (1973).

Jatav, H.S., S.K. Singh, Y. Singh and O. Kumar: Biochar and sewage sludge application increases yield and micronutrient uptake in rice (Oryza sativa L.). Communi. Soil Sci. Pl. Analy., DOI: 10.1080/00103624.2018.1474900 (2018).

Khanna, P.K., R.J. Raison and R.A. Falkiner: Chemical properties of ash derived from eucalyptus litter and its effects on forest soils. Forest Eco. Manag., 66, 107-125(1994).

Laird, D.A.: The charcoal vision: A win-win-win scenario for simultaneously producing bioenergy, permanently sequestering carbon, while improving soil and water quality. Agrono. J., 100, 178-181 (2008).

Lehmann, J. and S. Joseph: Biochar systems. In: Biochar for Environmental Management: Science and Technology (Eds. J. Lehmann and S. Joseph). Earthscan, London. pp. 147-168 (2009).

Lehmann, J. and M. Rondon: Biochar soil management on highly weathered soils in the humid tropics. In: Biological Approaches to Sustainable Soil Systems (Eds.: N. Uphoff, A.S. Ball, C. Palm, E. Fernandes, J. Pretty, H. Herren, P. Sanchez, O. Husson, N. Sanginga, M. Laing and J. Thies) Boca Raton, New York, pp. 517530 (2006).

Lehmann, J., D.C. Kern, L. German, J. Mccann, G.C. Martins and L. Moreira: Soil fertility and production potential. In: Amazonian Dark Earths: Origin, Properties, Management. Kluwer Academic Publishers, The Netherlands, pp. 105-124 (2003a).

Lehmann, J., D.C. Kern, B. Glaser and W.I. Woods: Amazonian Dark Earths: Origin, Properties and Management. Kluwer Academic Publishers, The Netherlands (2003b).

Lindsay, W.L. and W.A. Norwell: Development of DTPA soil test for zinc, iron, manganese and copper. Soil Sci. Soc. Amer. J., 42, 421-428 (1978).

Maji, A.K., G.P. Reddy and D. Sarkar: Acid Soils of India - their extent and spatial variability. NBSS Publ. No. 145, NBSS and LUP, Indian Council of Agricultural Research, Nagpur, pp. 1-138 (2012).

Manolikaki, I. and E. Diamadopoulos: Ryegrass yield and nutrient status after biochar application in two Mediterranean soils. Archives Agro. Soil Sci., 63, 1093-1107 (2016).

McDonald, M.R., C. Bakker and M.R. Motior: Evaluation of wood biochar and compost soil amendment on cabbage yield and quality. Can. J. Plant Sci., 99, 624-638 (2019).

Narambuye, F.X. and R.J. Haynes: Effect of organic amendments on soil $\mathrm{pH}$ and $\mathrm{Al}$ solubility and use of laboratory indices to predict their liming effect. Soil Sci., 17, 754-763 (2006).

Obour, P.B., E.O. Danso, N. Pouladi, S.A. Mickson, E.B. Sabi, F. Monnie and E. Arthur: Soil structure characteristics, functional properties and consistency limits response to corn cob biochar particle size and application rates in a 36-month pot experiment. Soil Res., 58, 488-497 (2020).

Opala, P.A., J.R. Okalebo and C.O. Othieno: Effects of organic and inorganic materials on soil acidity and phosphorus availability in a soil incubation study. ISRNAgron., 59, 1-10 (2012).

Raison, R.J.: Modification of the soil environment by vegetation fires, with particular reference to nitrogen transformation: A review. Plant and Soil, 51, 73-108 (1979).

Rondon, M., J.A. Ramirez and J. Lehmann: Charcoal additions reduce net emissions of greenhouse gases to the atmosphere. In: Proceedings of $3^{\text {rd }}$ USDA Symposium on Greenhouse Gases and Carbon Sequestration. Baltimore, USA(2005). 
Rondon, M.A., J. Lehmann, J. Ramírez and M. Hurtadoe: Biological nitrogen fixation by common beans (Phaseolus vulgaris L.) increases with bio-char additions. Bio. Fert. Soils, 43, 699-708 (2007).

Smider, B. and B. Singh: Agronomic performance of a high ash biochar in two contrasting soils. Agr. Ecosyst. Environ., 191, 99-107 (2014).

Sohi, S., E. Krull, E. Lopez-Capel and R. Bol: A review of biochar and its use and function in soil. Adv. Agron., 105, 47-82 (2010).

Steiner, C., B. Glaser, W.G. Teixeira, J. Lehmann and W.Z.W. Blum: Nitrogen retention and plant uptake on a highly weathered central Amazonian Ferralsol amended with compost and charcoal. J. PI. Nutr. Soil Sci., 171, 893-899 (2008).

Subbiah, B.V. and G.L. Asija: A rapid procedure for the determination of available nitrogen in soil. Curr. Sci., 25, 259-260 (1956).

Syuhada, A.B., J. Shamshuddin, C.I. Fauziah, A.B. Rosenani and A. Arifin: Biochar as soil amendment: Impact on chemical properties and corn nutrient uptake in a Podzol. Can. J. Soil Sci., 96, 400-412 (2016).

Tryon, E.H.: Effect of charcoal on certain physical, chemical, and biological properties of forest soils. Ecol. Monogr., 18, 81-115 (1948).

Usman, A., A.M.I. Wabel, S.Y. Ok and A.A. Harbi: Conocarpus biochar induces changes in soil nutrient availability and tomato growth under saline irrigation. Pedosp., 26, 27-38 (2016).
Uzoma, K.C., M. Inoue, H. Andry, H. Fujimaki, A. Zahoor and E. Nishihara: Effect of cow manure biochar on maize productivity under sandy soil condition. Soil Use Mgt., 27, 205-212 (2011).

Warnock, D.D., J. Lehmann, T.W. Kuyper and M.C. Rillig: Mycorrhizal responses to biochar in soil-concepts and mechanisms. Plant and Soil, 300, 9-20 (2007).

Yamato, M., Y. Okimori, I.F. Wibowo, S. Anshori and M. Ogawa: Effects of the application of charred bark of Acacia mangium on the yield of maize, cowpea and peanut, and soil chemical properties in South Sumatra, Indonesia. Soil Sci. PI. Nutri., 52, 489-495 (2006).

Yanai, Y., K. Toyota and M. Okazani: Effects of charcoal addition on $\mathrm{N}_{2} \mathrm{O}$ emissions from soil resulting from rewetting air-dried soil in shortterm laboratory experiments. J. Soil Sci. PI. Nutr., 53, 181-188 (2007).

Zhang, H., R.P. Voroney, G.W. Price and A.J. White: Sulfur-enriched biochar as a potential soil amendment and fertiliser. Soil Res., 55, 93-99 (2017).

Zhu, Q.H., X.H. Peng, T.Q. Huang, Z.B. Xie and N.M. Holden: Effect of biochar addition on maize growth and nitrogen use efficiency in acidic red soils. Pedosp., 24, 699-708 (2014).

Zwieten, V.L., S. Kimber, S. Morris, K.Y. Chan, A. Downie, J. Rust, S. Joseph and A. Cowie: Effects of biochar from slow pyrolysis of paper mill waste on agronomic performance and soil fertility. Plant and Soil, 327, 235-246 (2010). 